\title{
Speedup and fracturing of George VI Ice Shelf, Antarctic Peninsula
}

\author{
T. O. Holt ${ }^{1}$, N. F. Glasser ${ }^{1}$, D. J. Quincey ${ }^{2}$, and M. R. Siegfried ${ }^{3}$ \\ ${ }^{1}$ Centre for Glaciology, Institute of Geography and Earth Sciences, Aberystwyth University, Aberystwyth SY23 3DB, UK \\ ${ }^{2}$ School of Geography, University of Leeds, Leeds LS2 9JT, UK \\ ${ }^{3}$ Scripps Institution of Oceanography, UCSD, 9500 Gilman Drive, La Jolla CA 92093, USA \\ Correspondence to: T. O. Holt (toh08@aber.ac.uk)
}

Received: 5 December 2012 - Published in The Cryosphere Discuss.: 24 January 2013

Revised: 9 April 2013 - Accepted: 11 April 2013 - Published: 6 May 2013

\begin{abstract}
George VI Ice Shelf (GVIIS) is located on the Antarctic Peninsula, a region where several ice shelves have undergone rapid breakup in response to atmospheric and oceanic warming. We use a combination of optical (Landsat), radar (ERS 1/2 SAR) and laser altimetry (GLAS) datasets to examine the response of GVIIS to environmental change and to offer an assessment on its future stability. The spatial and structural changes of GVIIS (ca. 1973 to ca. 2010) are mapped and surface velocities are calculated at different time periods (InSAR and optical feature tracking from 1989 to 2009) to document changes in the ice shelf's flow regime. Surface elevation changes are recorded between 2003 and 2008 using repeat track ICESat acquisitions. We note an increase in fracture extent and distribution at the south ice front, ice-shelf acceleration towards both the north and south ice fronts and spatially varied negative surface elevation change throughout, with greater variations observed towards the central and southern regions of the ice shelf. We propose that whilst GVIIS is in no imminent danger of collapse, it is vulnerable to ongoing atmospheric and oceanic warming and is more susceptible to breakup along its southern margin in ice preconditioned for further retreat.
\end{abstract}

\section{Introduction}

\subsection{Background}

In recent years, several Antarctic Peninsula (AP) ice shelves have undergone dramatic and rapid retreat (Cook and Vaughan, 2010): for example, Prince Gustav Channel ice shelf (Rott et al., 1996; Cooper, 1997; Glasser et al., 2011), Larsen Inlet (Skvarca, 1993), Larsen A (Rott et al., 1998;
Doake et al., 1998), Larsen B (Rott et al., 2002; Glasser and Scambos, 2008), Jones (Fox and Vaughan, 2005), Wordie (Reynolds, 1988; Vaughan, 1993) and Müller (Ward, 1995). During 1998, 2008 and 2009, the Wilkins Ice Shelf experienced major breakup phases (Braun et al., 2009; Scambos et al., 2009; Padman et al., 2012) that highlighted the ongoing cryospheric response to atmospheric (Vaughan et al., 2003) and oceanic (Martinson et al., 2008) warming.

Ice-shelf stability on the AP has been linked to the southward migration of a critical atmospheric thermal boundary by a number of previous studies, linked to a rapid warming in the 1980s and 1990s. Morris and Vaughan (2003) remarked that the timing of ice-shelf collapse events was closely linked to the arrival of the $-9{ }^{\circ} \mathrm{C}$ mean-annual isotherm. During 2000, this isotherm stretched from the Wilkins Ice Shelf embayment, across Alexander Island and George VI Ice Shelf (GVIIS), before extending along the AP to Jason Peninsula north of Larsen C Ice Shelf (Fig. 1). It has also been noted that ice shelves respond to variations in oceanic temperature and circulation (e.g. Shepherd et al., 2004; Holland et al., 2010; Bindschadler et al., 2011; Pritchard et al., 2012), and through associated effects such as decreasing sea ice extents (Yuan and Martinson, 2000; Parkinson and Cavalieri, 2012) that may increase iceberg-calving rates from ice shelves through increased wave propagation (Brunt et al., 2011). Attributing specific ice-shelf changes to a single mechanism is still challenging, however, due to the complexity of oceanice-atmosphere interactions.

Several common glaciological characteristics have been identified on those ice shelves that have recently exhibited breakup phases; ice-shelf collapse is typically preceded by the following: (1) sustained ice-front retreat, resulting in a frontal geometry that bows inwards towards its centre from 


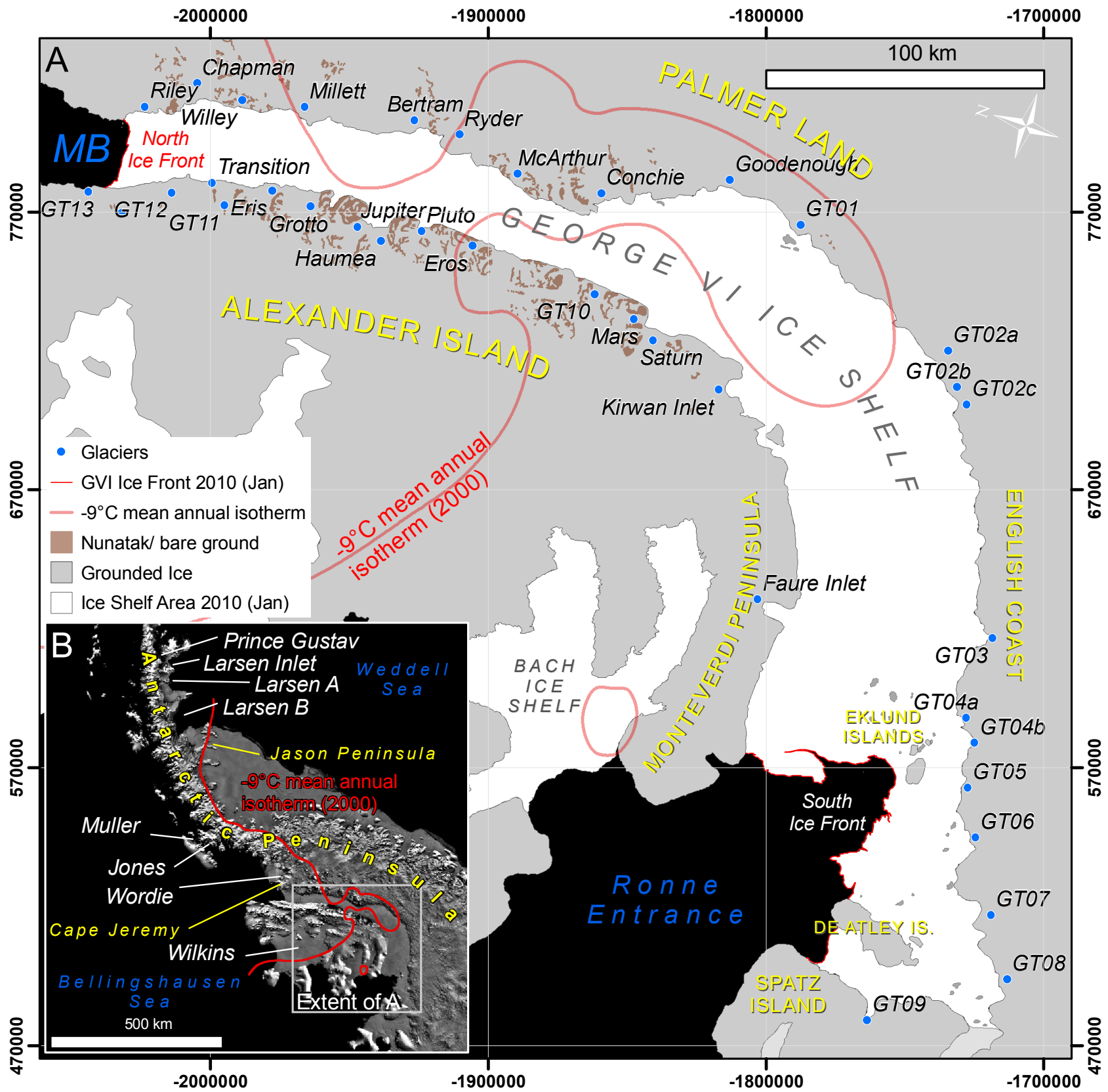

Fig. 1. (A) George VI Ice Shelf with localities mentioned in the text and its key tributary glaciers. The names of tributary glaciers were taken from the Antarctic Place-names Committee (http://www.antarctica.ac.uk/apc/) except for those labelled "GT\#\#" that were otherwise previously unnamed. Note the positioning of the $-9^{\circ} \mathrm{C}$ mean annual isotherm across Alexander Island (source: Morris and Vaughan, 2003). $\mathrm{MB}=$ Marguerite Bay. (B) The Antarctic Peninsula region displaying localities mentioned in the text, including the embayments of former ice shelves.

both lateral pinning points (Doake et al., 1998); (2) continued thinning from atmospheric or oceanic warming (Shepherd et al., 2004; Fricker and Padman, 2012); (3) an increase in flow speed (Rack et al., 2000; Rack and Rott, 2004; Vieli et al., 2007); and (4) structural weakening, typically along suture zones (Glasser and Scambos, 2008), but also transverse to flow due to changing stress regimes within the ice shelf
(Braun et al., 2009). It has also been suggested that extensive meltwater on the ice-shelf surface acts as a driving force in fracture propagation that preconditions the ice shelf for rapid retreat (Scambos et al., 2000, 2003; MacAyeal et al., 2003), although the winter breakup events of the Wilkins Ice Shelf suggested that this is not a precursor for all collapse phases (see Scambos et al., 2009). Other factors such as embayment 
geometry (Fox and Vaughan, 2005) and the presence of ice rises (Hughes, 1983; Reynolds, 1988; Doake and Vaughan, 1991) also impact the response of individual ice shelves.

It has been shown that an ice shelf acts as a buttress to grounded ice, thus controlling the dynamics and response time of the inland ice sheet. Rott et al. (2002, 2007), De Angelis and Skvarca (2003), Scambos et al. (2004), Hulbe et al. (2008), Glasser et al. (2011) and Rignot et al. (2011b) have all demonstrated a speedup of tributary glaciers following ice-shelf collapse, with Rott et al. (2004) illustrating that such tributaries can accelerate between three and nine times their pre-collapse state. Furthermore, individual glaciers have been shown to undergo increased thinning following ice-shelf collapse (e.g. Hulbe et al., 2008; Glasser et al., 2011; Berthier et al., 2012). Consequently, the rate at which grounded ice discharges into the ocean is increased and thus their contribution to global sea level is amplified.

Despite the uncertainty surrounding the stability of the remaining AP ice shelves, few studies have considered their long-term structural and dynamic evolution, even though Mercer (1978) and Vieli et al. (2007) both recognised that glaciological changes occurred well in advance of breakup phases. Here, we use optical, radar and laser altimeter satellite remote sensing data to (1) assess the spatial and structural evolution of GVIIS from ca. 1973 to ca. 2010, (2) calculate multi-annual flow speeds of the ice-shelf surface from ca. 1989 to ca. 2009, and (3) analyse surface-elevation change from ICESat GLAS data between 2003 and 2008. We use these results to highlight glaciological changes of GVIIS, in response to climatic and oceanic variation and place these observations in the context of ice-shelf collapse elsewhere in the Antarctic Peninsula.

\section{George VI ice shelf}

\subsection{Overview}

GVIIS is situated in the south-west AP, and has been the subject of much research since the British Graham Land Expedition (1934-1937) (e.g. Fleming et al., 1938; Wager, 1972; Pearson and Rose, 1983; Reynolds and Hambrey, 1988; Lucchitta and Rosanova, 1998; Smith et al., 2007; Humbert, 2007; LaBarbera and MacAyeal, 2011). The ice shelf occupies George VI Sound, situated between Alexander Island and Palmer Land, and covers an area of approximately $24000 \mathrm{~km}^{2}$ (Fig. 1); it is the second largest ice shelf remaining on the AP. GVIIS has two ice fronts: a northern ice front that calves into Marguerite Bay, and a southern ice front that terminates into the Ronne Entrance that is interrupted by a succession of ice rises (Eklund Islands and De Atley Island). The distance between the two fronts is approximately $450 \mathrm{~km}$ along its centreline. The northern front sits in a channel $\sim 20 \mathrm{~km}$ wide, with the southern margin measuring $\sim 75 \mathrm{~km}$ from Monteverdi Peninsula to the English Coast.
The ice shelf varies in thickness from $100 \mathrm{~m}$ at the northern ice front to $600 \mathrm{~m}$ in the central region, before thinning again towards the southern ice front (Talbot, 1988; Lucchitta and Rosanova, 1998; Smith et al., 2007).

The ice shelf catchment covers much of the eastern coast of Alexander Island and the western margin of Palmer Land, with $12 \mathrm{~km}^{3} \mathrm{a}^{-1}$ and $46 \mathrm{~km}^{3} \mathrm{a}^{-1}$ of ice estimated to be flowing into GVIIS, respectively (Reynolds and Hambrey, 1988). Ice from Alexander Island only extends a few kilometres into the ice-shelf system (Lucchitta and Rosanova, 1998) as tributary glaciers are generally small (between $54 \mathrm{~km}^{2}$ and $144 \mathrm{~km}^{2}$; Humbert, 2007). Glaciers flowing from Palmer Land are typically larger and supply much of the ice to GVIIS (Humbert, 2007). This domination of inflow from Palmer Land produces stagnation points along the ice shelf, created as ice flows towards the opposite grounding line, but diverges prior to reaching this point (Reynolds and Hambrey, 1988). Bentley et al. $(2005,2011)$ and Roberts et al. (2008) both show that during the mid-Holocene, George VI Sound was absent of shelf ice, and thus the present day ice shelf is still considered vulnerable to environmental change despite its atypical dynamic configuration.

\subsection{Ice-shelf mass balance}

Wintertime snowfall on GVIIS rarely lasts through the summer season due to high surface melt rates, particularly in the northern regions where extensive meltpools develop over an ice-shelf area of $\sim 5900 \mathrm{~km}^{2}$ each year (Wager, 1972; Ridley, 1993; Smith et al., 2007), which subsequently refreezes on the ice-shelf surface during the austral winter (Reynolds, 1981). Consequently, limited mass is lost through surface melting. The ice shelf thus consists of largely consolidated ice, fed from inland glacier systems (Humbert, 2007).

Mass loss occurs almost entirely as a result of seasonalfrontal calving and basal melting (Pearson and Rose, 1983; Reynolds and Hambrey, 1988; Lennon et al., 1982), with Potter and Paren (1985) suggesting that the ice fronts of GVIIS advance periodically before calving along rifts that penetrate the entire depth of the ice shelf. Mercer (1978), Doake (1982), Lucchitta and Rosanova (1998), Smith et al. (2007) and Cook and Vaughan (2010) used a combination of historical accounts and satellite imagery to document the fluctuation of the ice-shelf margins. Between 1947 and 2008, $1939 \mathrm{~km}^{2}$ of ice was lost from the northern and southern ice fronts combined, with no significant advance (Lucchitta and Rosanova, 1998; Cook and Vaughan, 2010). Despite these studies there is little analysis of the spatial or temporal patterns of retreat over time.

GVIIS has high basal melt rates (e.g. Jenkins and Jacobs, 2008; Holland et al., 2010). Warm water intrusion from the Circumpolar Deep Water (CDW) current, originating from the south-east Pacific basin, flows onto the continental shelf and extends underneath the entire length of GVIIS, contributing significantly to basal melt (Potter et al., 1984; Potter and 
Paren, 1985; Talbot, 1988; Lucchitta and Rosanova, 1998; Holland et al., 2010). This process is thought to be linked to the strength of the Antarctic Circumpolar Current (ACC) and a cross-current bathymetric low (Klinck and Smith, 1993). The circulation involves dense saline CDW water advecting from Marguerite Bay beneath GVIIS via its northern ice front. Upwelling of warmer water instigates basal melting, which is first deflected westwards by the Coriolis force, and subsequently advected northwards, completing the cycle (Potter and Paran, 1985; Smith et al., 2007). The maximum observed oceanic temperature from within George VI Sound is $+1.1{ }^{\circ} \mathrm{C}, 3{ }^{\circ} \mathrm{C}$ warmer than the freezing point at the base of the ice (Talbot, 1988).

Potter et al. (1984) calculated spatially averaged basal melt rates to be $2.1 \mathrm{~m} \mathrm{a}^{-1}$ in order for GVIIS to remain in equilibrium; recent basal-melt calculations suggest spatially averaged losses of $2.8 \mathrm{~m} \mathrm{a}^{-1}, 4.1 \mathrm{~m} \mathrm{a}^{-1}, 3.0 \mathrm{~m} \mathrm{a}^{-1}$ and $6.0 \mathrm{~m} \mathrm{a}^{-1}$ (Corr et al., 2002; Jenkins and Jacobs, 2008; Holland et al., 2010; Dinniman et al., 2012, respectively) revealing that the ice shelf is currently estimated to be in negative mass balance, correlating well with the sustained thinning rates reported by Fricker and Padman (2012) and Pritchard et al. (2012). Here, we assess surface elevation changes with respect to spatial, structural and dynamic configurations of the ice shelf to investigate ice-shelf response to recent climatic changes.

\subsection{Structural glaciology}

Reynolds (1981) and Reynolds and Hambrey (1988) assessed the surface features and structures of the northern regions of GVIIS, concentrating on meltpools, longitudinal structures and crevasse patterns. Their analysis revealed a highly compressive flow regime fed by Palmer Land glaciers that was later emphasised by LaBarbera and MacAyeal (2011) through numerical modelling of structural development and Humbert (2007), who modelled ice-shelf velocities. Despite these studies there have been no dynamic or structural investigations carried out along the northern ice front, or in the southern region of GVIIS. Thus, there is no documented evidence of any structural or dynamic changes, despite it being one of the most intensely studied systems in the region and being situated both near the thermal limit of viability (Morris and Vaughan, 2003) and in a warming Bellingshausen Sea (Holland et al., 2010).

\section{Methods}

\subsection{Structural and spatial assessment}

Structural and spatial mapping was carried out in ArcMap 9.3 geographical information system (GIS) software following similar procedures to Glasser and Scambos (2008) and Braun et al. (2009). Features were mapped from six Landsat MultiSpectral Scanner (MSS), three Thermatic Mapper (TM), nine
Enhanced TM Plus (ETM+) images and three ERS-2 SAR scenes (see Supplement). Mapping was performed using image bands that offered the best pixel and spectral resolution: for example, Landsat MSS Band 5 (0.6-0.7 $\mu \mathrm{m}$, 80 m), Landsat TM/ETM+ Band $4(0.76-0.9 \mu \mathrm{m}, 30 \mathrm{~m})$ and Landsat ETM+ Panchromatic Band $8(0.52-0.9 \mu \mathrm{m}, 15 \mathrm{~m})$. Digitised features included the location of the ice front and iceshelf grounding zone for spatial assessment, rifts, fracture traces, crevasses and crevassed zones (fields), longitudinal structures (elsewhere termed flowstripes, flow bands, foliation, streaklines), pressure ridges, ice rises and ice rumples (Table 1).

Digitising was carried out at three main scales for consistency across all satellite scenes: (1) 1:100000 was used for large surface features such as longitudinal structures, (2) 1:50000 was used for fractures, rifts, the ice front and the grounding zone, and (3) $1: 25000$ was used for crevasses, crevassed zones, transverse structures and pressure ridges. Other features, such as nunataks and ice rises, were mapped at scales appropriate to their individual characteristics. For areas where significant change was observed, further mapping was carried out to provide detail of short-term changes at finer spatial resolutions.

\subsection{Flow-speed derivation}

\subsubsection{Interferometric SAR}

InSAR procedures were carried out in GAMMA Remote Sensing software using two ERS-1/2 $24 \mathrm{~h}$ repeat image pairs over the northern ice front for ca. 1995; one image pair was used to construct an ascending-pass interferogram, with the other image pair used to construct a descending-pass interferogram. Velocity fields of the ice-shelf surface were then resolved via a trigonometric approach between the ascending and descending interferograms, assuming that the surface dynamics had not altered between the different image pair acquisitions (28/29 October 1995, 15/16 February 1996), and that flow was in the horizontal plane. Tide corrections were applied to both the ascending and descending interferograms using the CATS2008a tidal model (Padman et al., 2002; King and Padman, 2005). The $24 \mathrm{~h}$ velocity fields were then scaled up to annual displacements for comparison with the manually derived feature tracking data. Atmospheric effects and baseline estimation errors are likely to be the largest inherent contributors to uncertainty in the resulting data (Mohr et al., 2003), but are no greater than $5 \mathrm{~m} \mathrm{a}^{-1}$. Residual uncertainties caused by vertical ice-shelf motion are estimated to be no more than $\pm 20 \mathrm{~m} \mathrm{a}^{-1}$.

\subsubsection{Manual optical feature tracking}

Following the work of Simmons and Rouse (1984) and Simmons (1986), manual feature tracking was used to calculate surface speeds of GVIIS. We opted for manual feature 
Table 1. Ice-shelf features, identifying criteria and significance. Adapted from Glasser and Scambos (2008) and Glasser et al. (2009). See Fig. 2 for full structural map of GVIIS and Figs. 4 and 5 for the north and south ice fronts, respectively.

\begin{tabular}{|c|c|c|}
\hline Feature & Identification & Significance \\
\hline Ice front & $\begin{array}{l}\text { Sharp transition from ice shelf to open ocean (summer) } \\
\text { or sea ice (winter, fast ice). Often seen as a bright sunlit } \\
\text { or dark shaded sub-linear feature. Sea ice or icebergs } \\
\text { often visible close to the edge indicative of active calv- } \\
\text { ing. }\end{array}$ & $\begin{array}{l}\text { Clear indicator of the maximum ice-shelf extent for a } \\
\text { particular time period. Sequential images can track the } \\
\text { fluctuation of the ice margin to develop an understanding } \\
\text { of ice-front dynamics. }\end{array}$ \\
\hline Rift & $\begin{array}{l}\text { Ice-shelf surface fracture with a visible opening often } \\
\text { perpendicular to the principal ice-flow direction. Rifts } \\
\text { that reach the water line can be filled with ice melange } \\
\text { or sea water. Some rifts may penetrate the entire thick- } \\
\text { ness of the ice shelf. }\end{array}$ & $\begin{array}{l}\text { Typically formed when the ice exceeds a critical stress- } \\
\text { dependant threshold. Rifts form perpendicular to the di- } \\
\text { rection of maximum tension (Khazendar and Jenkins, } \\
2003 \text { ). Some surface rifts may be a product of basally } \\
\text { formed crevasses, with the surface lowering in response } \\
\text { to hydrostatic rebalancing (Luckman et al., 2012; Mc- } \\
\text { Grath et al., 2012). }\end{array}$ \\
\hline $\begin{array}{l}\text { Crevasses and } \\
\text { crevasse fields }\end{array}$ & $\begin{array}{l}\text { Surface fractures appearing as dark (open or water- } \\
\text { filled) or bright (snow-covered) linear lines. Often form } \\
\text { in distinct zones. In this study, the term crevasse is ap- } \\
\text { plied to fractures originating on grounded ice to differ- } \\
\text { entiate them from ice-shelf fractures that form in float- } \\
\text { ing ice. }\end{array}$ & $\begin{array}{l}\text { Formed when the stresses within the ice exceed a given } \\
\text { threshold. Form perpendicular to the direction of maxi- } \\
\text { mum tension. Open crevasses indicate extensional flow } \\
\text { regimes (Paterson, 1994) }\end{array}$ \\
\hline Fracture trace & $\begin{array}{l}\text { Resembles a fracture or rift on the ice-shelf surface, } \\
\text { but where no clear opening is observed. Naturally form } \\
\text { down ice of rifts. }\end{array}$ & $\begin{array}{l}\text { Formed when ice is compressed perpendicularly (or ap- } \\
\text { proximately) to the orientation of the original fracture } \\
\text { and/or rift. }\end{array}$ \\
\hline $\begin{array}{l}\text { Longitudinal } \\
\text { surface structures } \\
\text { (flowstripes, } \\
\text { streaklines) }\end{array}$ & $\begin{array}{l}\text { Long, linear structures aligned parallel with the princi- } \\
\text { pal flow direction. Typically }<1 \mathrm{~km} \text { in width, but often } \\
\text { exceeding tens to hundreds of km in length. Observed } \\
\text { as dark and light lines caused by shaded relief. Origi- } \\
\text { nate from the confluence of two flow units and in re- } \\
\text { gions of positive relief, at bed protuberances or in re- } \\
\text { gions of high basal friction. }\end{array}$ & $\begin{array}{l}\text { Generally indicate regions of faster ice flow (Camp- } \\
\text { bell et al., 2008) and depict suture zones of different } \\
\text { flow units (Glasser and Gudmundsson, 2012). Cumula- } \\
\text { tive length is due to the slow decay timescale relative to } \\
\text { the time required for ice to travel a long distance. }\end{array}$ \\
\hline $\begin{array}{l}\text { Transverse struc- } \\
\text { tures }\end{array}$ & $\begin{array}{l}\text { Term given to sub-linear surface features where no } \\
\text { clear method of formation exists. Appear as dark lines } \\
\text { on the ice-shelf surface. }\end{array}$ & $\begin{array}{l}\text { May indicate degraded (or filled) surface rifts or surface } \\
\text { undulations caused by ice-shelf thickening under com- } \\
\text { pressive stresses. Significance discussed on a case-by- } \\
\text { case basis. }\end{array}$ \\
\hline Pressure ridges & $\begin{array}{l}\text { Succession of dark and light linear bands appearing } \\
\text { perpendicular to principal flow direction. Often located } \\
\text { near bedrock or ice rises or between coalescing flow } \\
\text { units. }\end{array}$ & $\begin{array}{l}\text { Formed by ice straining vertically under compressive } \\
\text { stresses, particularly as ice approaches ice rises or be- } \\
\text { tween ice stream confluences (Collins and McCrae, } \\
\text { 1985) }\end{array}$ \\
\hline Grounding zone & $\begin{array}{l}\text { Sudden break in surface slope or area of intense } \\
\text { crevassing. Meltwater ponds tend to form at the ground- } \\
\text { ing zone where there is a change of gradient. }\end{array}$ & $\begin{array}{l}\text { Junction between grounded ice and floating ice. A } \\
\text { dynamic zone flexing with tidal amplitude (Vaughan, } \\
\text { 1995). }\end{array}$ \\
\hline Ice rises & $\begin{array}{l}\text { Elevation of the ice-shelf surface with disturbance to } \\
\text { ice flow indicated by pressure ridges on the stoss side } \\
\text { and/or crevasses in the lee of the ice rise. }\end{array}$ & $\begin{array}{l}\text { Local bedrock high where the ice shelf becomes } \\
\text { grounded. }\end{array}$ \\
\hline Ice rumples & $\begin{array}{l}\text { Elevation of the ice-shelf surface with disturbance to } \\
\text { ice flow indicated by crevasses. }\end{array}$ & $\begin{array}{l}\text { Local bedrock high where the ice shelf is partially } \\
\text { grounded, but ice flow continues. May represent proto } \\
\text { or corpse ice rises (Swithinbank et al., 1988). }\end{array}$ \\
\hline Surface meltwater & $\begin{array}{l}\text { Dark, flat areas on ice-shelf surface either as open } \\
\text { or closed systems. May or may not form along pre- } \\
\text { existing structural discontinuities. }\end{array}$ & $\begin{array}{l}\text { Indicates surface ablation and can indicate ice-shelf flow } \\
\text { orientation. Assessing time series of surface meltwater } \\
\text { can indicate increasing/decreasing atmospheric temper- } \\
\text { atures. }\end{array}$ \\
\hline Ice dolines & $\begin{array}{l}\text { Large sub-rounded surface hollows often filled with } \\
\text { meltwater during the height of the melt season. }\end{array}$ & $\begin{array}{l}\text { May indicate a link between the ice-shelf surface and } \\
\text { subsurface. Considered to be located in thin and weak } \\
\text { ice. Formation linked to a change in surface melting } \\
\text { conditions either by flow or by climate change (Bind- } \\
\text { schadler et al., 2002). }\end{array}$ \\
\hline
\end{tabular}


tracking methods over automated alternatives due to the considerable variations in surface feature scale, the ability to map displacements between multiple coincident scenes, and the capability of tracking features through fine clouds or atmospheric haze.

Optical datasets were selected for manual feature tracking as the visual quality of the imagery is far superior to that of SAR data. Furthermore, by using Landsat data the temporal resolution was extended back to 1986, thus creating an approximate $25 \mathrm{yr}$ window to assess changes in flow speed. In total, 40 Landsat scenes (see Supplement) were used over time periods of no more than $3 \mathrm{yr}$ between image pairs. Images were coregistered to within 1 pixel accuracy with mapping also carried out to an estimated accuracy of 1 pixel, thus resulting in a total maximum uncertainty of 2 pixels between image pairs.

Surface features were selected based on their distinctness between image pairs and their distribution across the image. Generally, rifts and fracture traces were used, although pressure ridges were also tracked where they could be identified clearly in both images. A polyline was digitised from the feature's starting point on image 1 to the same point on image 2 with the total polyline length (i.e. feature displacement) calculated and added to an attribute table within a GIS. The centre point for each polyline was resolved and similarly added to the attribute table as X and Y coordinates and later used as the interpolation point. The displacement measurements were then converted from absolute displacement to displacement in metres per annum. Normalising the measurements in this way permitted data collation between different image pairs. Next, the normalised displacements were merged into a single shapefile, representative of total displacement in $\mathrm{m} \mathrm{a}^{-1}$, for that particular time period. The data points were subsequently interpolated using a natural neighbour algorithm, selected over alternative algorithms as it performs equally well with regularly and irregularly distributed data (Watson, 1992).

This manual feature tracking approach works particularly well where distinct structures are densely packed rather than over featureless terrain. However, we assume that any large variation of flow is represented by visible surface structures (e.g. shear zones, pressure ridges), and indeed changes in these structures over time (rift development/propagation). We therefore suggest that where speeds have been derived from interpolation between sparsely distributed points, the true speed is within the boundaries of the stated uncertainties. Comparison of our ca. 2007 (north) and ca. 2009 (south) feature tracking results with the InSAR-derived velocities (ca. 2007) of Rignot et al. (2011a) show good agreement at both ice fronts.

\subsection{Surface-elevation change}

From 2003 to 2009, the Geoscience Laser Altimeter System (GLAS) on-board NASA's Ice, Cloud, and land Ele- vation Satellite (ICESat) measured Earth surface elevations between $\pm 86^{\circ}$ latitude. With a surface footprint of $50-70 \mathrm{~m}$, GLAS collected data every $172 \mathrm{~m}$ along track in 33-day campaigns two to three times per year. Since ice-shelf analysis requires accurate, tide-corrected elevation measurements, the GLAS data (GLA12, release 531) were "retided" by adding back the GOT99.2 tide correction (Fricker and Padman, 2006). This dataset was then converted to a WGS-84 ellipsoid and then corrected for vertical tidal displacements using the more accurate CATS2008a model (Padman et al, 2002; King and Padman, 2005), the inverse barometer effect (IBE, Brunt et al., 2010) and inter-campaign biases (Siegfried et al., 2011). After applying corrections, we filtered data from campaigns affected by clouds by inspection of gain and return energy values on a track-by-track basis and resampled each track to an ad hoc reference track (Brunt et al., 2010), which allowed for repeat-track analysis.

Because we were only interested in elevation changes, the absolute accuracy of the GLAS data is inconsequential. We determined a region-specific precision of our GLAS data using crossover points over a larger dataset also including Bach and Stange ice shelves on the AP (Holt, 2012) and iteratively removing outliers (following the methods of Brenner et al., 2007). The calculated single-shot precision of $0.153 \mathrm{~m}$ (1 standard deviation, $n=30$ ) is slightly higher than the calculated precision of ICESat data from early campaigns (Shuman et al., 2006), which is expected as the precision over ice shelves accounts for instrumental uncertainty as well as uncertainty in the IBE, tide, and inter-campaign bias corrections.

Following the pre-processing of the GLAS data, each track was converted to a polar stereographic projection to match other datasets in this study, and then subset to the ice-shelf area in hydrostatic equilibrium using the extents calculated by Brunt et al. (2010) to ensure that any variations in surface elevation reflected changes in ice-shelf thickness from either surface or basal accumulation/ablation. Next, GLAS data were further culled, removing any points potentially affected by the motion of ice-shelf surface undulations (i.e. fractures, rifts, pressure ridges, longitudinal structures) so that the resulting surface-elevation changes reflected a true elevation change rather than a change in position of surface structure. This process was similarly undertaken by Horgan et al. (2011), although instead of manually removing data, here the structural maps for ca. 2003 and ca. 2010 were used to automatically select and remove the elevation points in $\mathrm{Ar}$ cMap within $200 \mathrm{~m}$ of any distinct surface feature.

Finally, surface-elevation changes were calculated between comparable campaigns (i.e. on 12-monthly timescales or multiples thereof) to avoid elevation changes caused by short-term seasonal ablation and/or accumulation. The campaigns that offered the best spatial and temporal resolution for each individual track were selected, and whilst intercampaign elevations were not used in the final elevationchange assessments, a record of surface elevation changes 


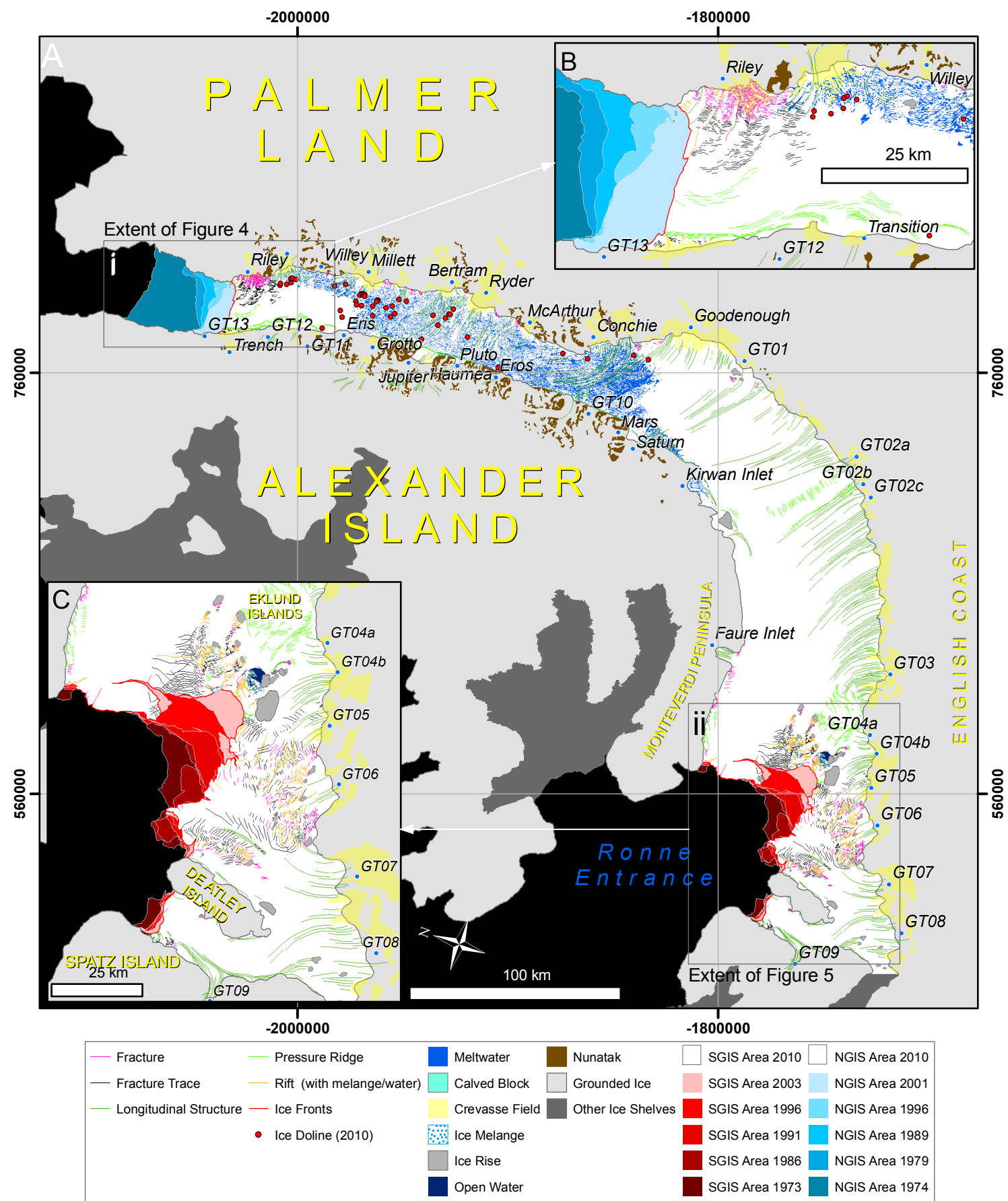

Fig. 2. (A) Glaciological structural overview (2010) illustrating the dominance of longitudinal structures, surface meltwater and rifts towards the south ice front (see Table 1 for a full list of identifying criteria and significance of ice-shelf structures and surface features). Retreat patterns of the northern (Ai, B) and southern (Aii, C) ice fronts are also illustrated: note in particular the large-scale breakup followed by more steady retreat at the north ice front and concentrated retreat in the central section of the south ice front between ca. 1973 and 2010.

was subsequently obtained that reflected a sub-decadal change. Repeat surface-elevation measurements were acquired over 16 ICESat tracks from a total of 4316 points and are displayed as change in $\mathrm{ma}^{-1}$. Datasets produced from these methods are summarised in Table 2, with a full list of satellite images used given in the Supplement. 
Table 2. Datasets produced for GVIIS.

\begin{tabular}{lllll}
\hline Ice Shelf & $\begin{array}{l}\text { Structural } \\
\text { assessment }\end{array}$ & $\begin{array}{l}\text { Spatial } \\
\text { assessment }\end{array}$ & Surface velocities & Surface-elevation change \\
\hline $\begin{array}{l}\text { George VI North/ } \\
\text { Central }\end{array}$ & $\begin{array}{l}1974,1979,1986, \\
1996,2001,2010\end{array}$ & $\begin{array}{l}1974,1979,1989,2001,2010 \\
1996,\end{array}$ & $\begin{array}{l}\text { ca. 1989, ca. 1995, } \\
\text { ca. 2002, ca. 2007 }\end{array}$ & October 2003-October 2008 \\
\hline George VI South & $\begin{array}{l}19763,1986,1991, \\
2003,2010\end{array}$ & $\begin{array}{l}1973,1986,1991, \\
1996,2003,2010\end{array}$ & $\begin{array}{l}\text { ca. 1989, ca. 2002, } \\
\text { ca. 2010 }\end{array}$ & October 2003-October 2008 \\
\hline
\end{tabular}

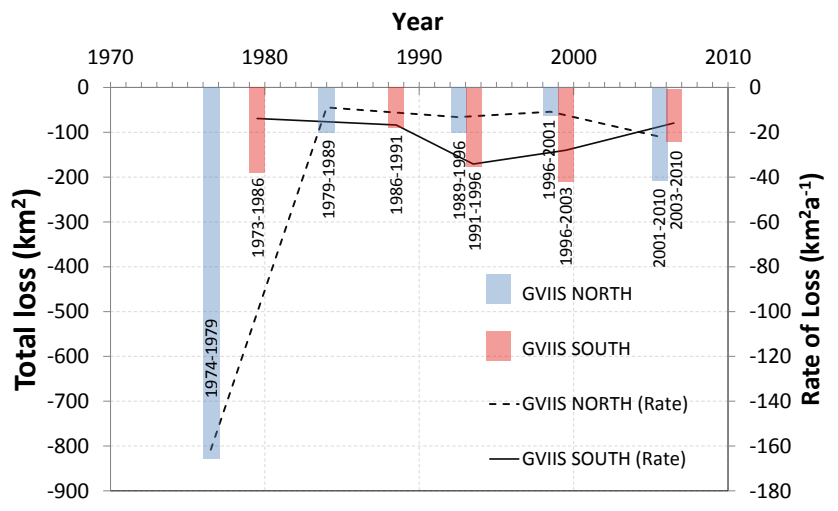

Fig. 3. Total ice loss (bars) and rate of loss (lines) for GVIIS north and GVIIS south ice fronts between ca. 1973 and 2010. Note the major ice loss event between 1974 and 1979 at the north ice front followed by a period of comparatively steady retreat. Loss at the south ice front is more regular across the observation period, although retreat rate doubles between 1990 and 1995. There is no relationship between ice loss quantity or timing between the north and south ice fronts.

\section{Results}

\subsection{Ice-front retreat}

Between 1974 and 1979 , approximately $820 \mathrm{~km}^{2}$ of ice calved off the north ice front (Figs. 2b, 3). Further retreat was recorded along the Palmer Land grounding zone between 1979 and 1989, 1989 and 1996, and from 1996 to 2001, whilst the Alexander Island pinning point remained relatively stable until retreating between 2001 and 2010. In total, $1255 \mathrm{~km}^{2}$ of ice was lost from the north ice front between 1974 and 2010, with the centre of the ice front retreating $40.6 \mathrm{~km}$ into George VI Sound. Post 1979, the retreat rate of the north ice front fluctuated between $-10 \mathrm{~km}^{2} \mathrm{a}^{-1}$ and $-20 \mathrm{~km}^{2} \mathrm{a}^{-1}$. Furthermore, a concave profile was observed at the north ice front in each of the observation periods.

At the south ice front, approximately $925 \mathrm{~km}^{2}$ of ice was lost, with $182 \mathrm{~km}^{2}$ of ice advancing into the Ronne Entrance (Fig. 2c, d and Fig. 3); a net loss of $743 \mathrm{~km}^{2}$ was thus recorded between January 1973 and January 2010. During $1973,390 \mathrm{~km}^{2}$ of shelf ice was captured calving off the south ice front towards Monteverdi Peninsula but not included in loss calculations as it was deemed to have already detached from the ice shelf. Between 1991 and 1996 there was an increase in the rate of retreat to a maximum of $-28.0 \mathrm{~km}^{2} \mathrm{a}^{-1}$, almost twice the rate in the previous $\left(-16.8 \mathrm{~km}^{2} \mathrm{a}^{-1}\right)$ and proceeding time periods $\left(-15.9 \mathrm{~km}^{2} \mathrm{a}^{-1}\right)$. Retreat was concentrated in the central portions of the south ice front, with only limited retreat observed at the ice-front pinning points along Monteverdi Peninsula, De Atley Island and Spatz Island. The continued retreat between January 2010 and March 2010 subsequently split the main ice front into two independent sections, South Ice Front 1 (SIF1) from Monteverdi Peninsula to the Eklund Islands and South Ice Front 2 (SIF2) from the Eklund Islands to De Atley Island. A smaller, third ice front between De Atley Island and Spatz Island is always independent over the timescales investigated here and is largely disconnected to the processes of the main ice shelf. The south ice front became increasingly concave between January 1973 and January 2010, although the retreat between 15th January 2010 and 24th March 2010 subsequently created two new slightly convex ice fronts.

\subsection{Structural glaciology and structural evolution}

Mapped structures and surface features (January 2010) are displayed in Fig. 2, with a full list of glaciological structures, identifying criteria and their significance provided in Table 2 . Here, we describe the structural evolution of the north and south ice fronts only.

\subsubsection{Structural evolution at the north ice front}

During 1974, ice flowing from Palmer Land into GVIIS was heavily rifted and could be traced towards the north ice front, becoming increasingly chaotic (Fig. $4 \mathrm{a}$ and $\mathrm{b}$ ). Brash ice was observed between some of the larger rifts, whereas in the central portion of the north ice front, large rifts were filled with smooth, uniform ice with some evidence of open water running along their lengths. These central rifts could be traced back intermittently (at $\sim 4 \mathrm{~km}$ distances) to the northern boundary of Riley Glacier whilst decreasing in their overall length. Rifts that eventually formed the ice front during 1979 and 1989 were also visible $\sim 25 \mathrm{~km}$ from the 1974 ice margin.

Chaotic rifting was also observed along the Palmer Land margin of the northern section during 1979, 2001 and 2010 


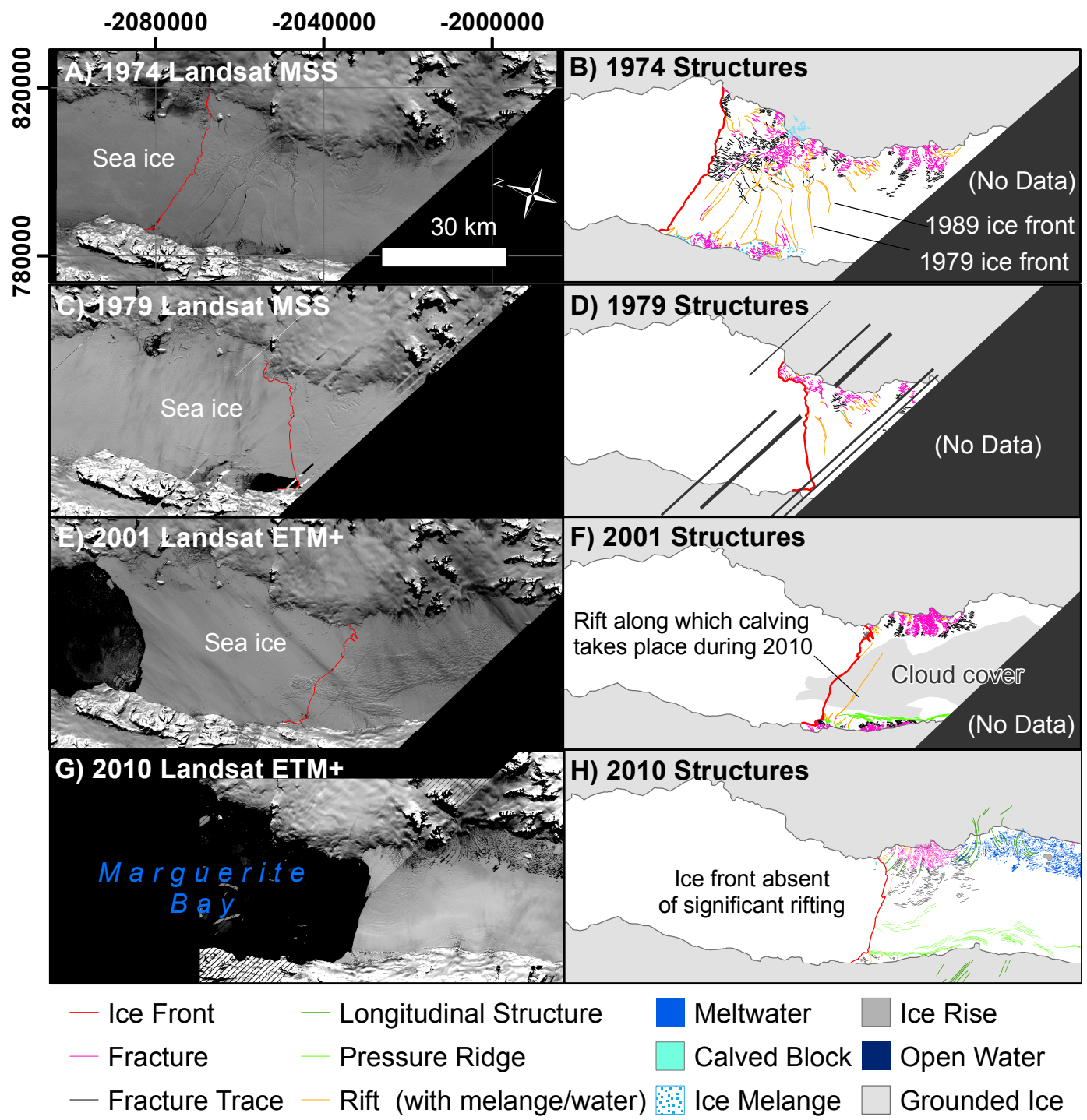

Fig. 4. Structural evolution at the north ice front illustrating widespread rifting that encouraged retreat. Note the long-term development of rifts (B) from the eastern grounding line that eventually form the frontal profile during 1979 and 1989. Post 2001 there are few ice-shelf-wide rifts at the northern ice front.

(Fig. 4). During 2001, several distinct rifts had developed along the Alexander Island margin, the largest of which had propagated across the ice shelf for $\sim 20 \mathrm{~km}$ that later facilitated iceberg calving between 6 January 2010 and 29 January 2010. This event was captured by the Landsat ETM + sensor, but detailed observation is limited due to poor data quality and thus not shown here. Few rifts were observed along the north ice front during March 2010, with the exception of some small features at each of the grounding zones (Fig. 4h).

\subsubsection{Structural evolution at the south ice front}

During 1973 (Fig. 5a and b), ice feeding the centre of the south ice front was dominated by cross-cutting fracture traces, emanating from rifts lee side of the Eklund Islands further upstream. The largest rifts were filled with unconsolidated brash ice, with occasional small pools of open water. Rifts also formed along the English Coast margin immediately downstream of ice rises and headlands. These spread for up to $20 \mathrm{~km}$ into the ice shelf before becoming indistinct from the surrounding ice.

In both of these regions, rifts continued to propagate throughout the observation period assessed here. During 1986 (Fig. 5c and d), 1991 (Fig. 5e and f), 2003 (Fig. 5g and $h$ ) and 2010 (Fig. 5i and j), the area of rifted shelf ice increased towards a retreating ice front, with more rifts showing evidence of open water or unconsolidated ice along their length, suggesting that they at least reach the water line. Some of the identified rifts towards the southern ice front are likely to be a surface characteristic of basal crevasses, 


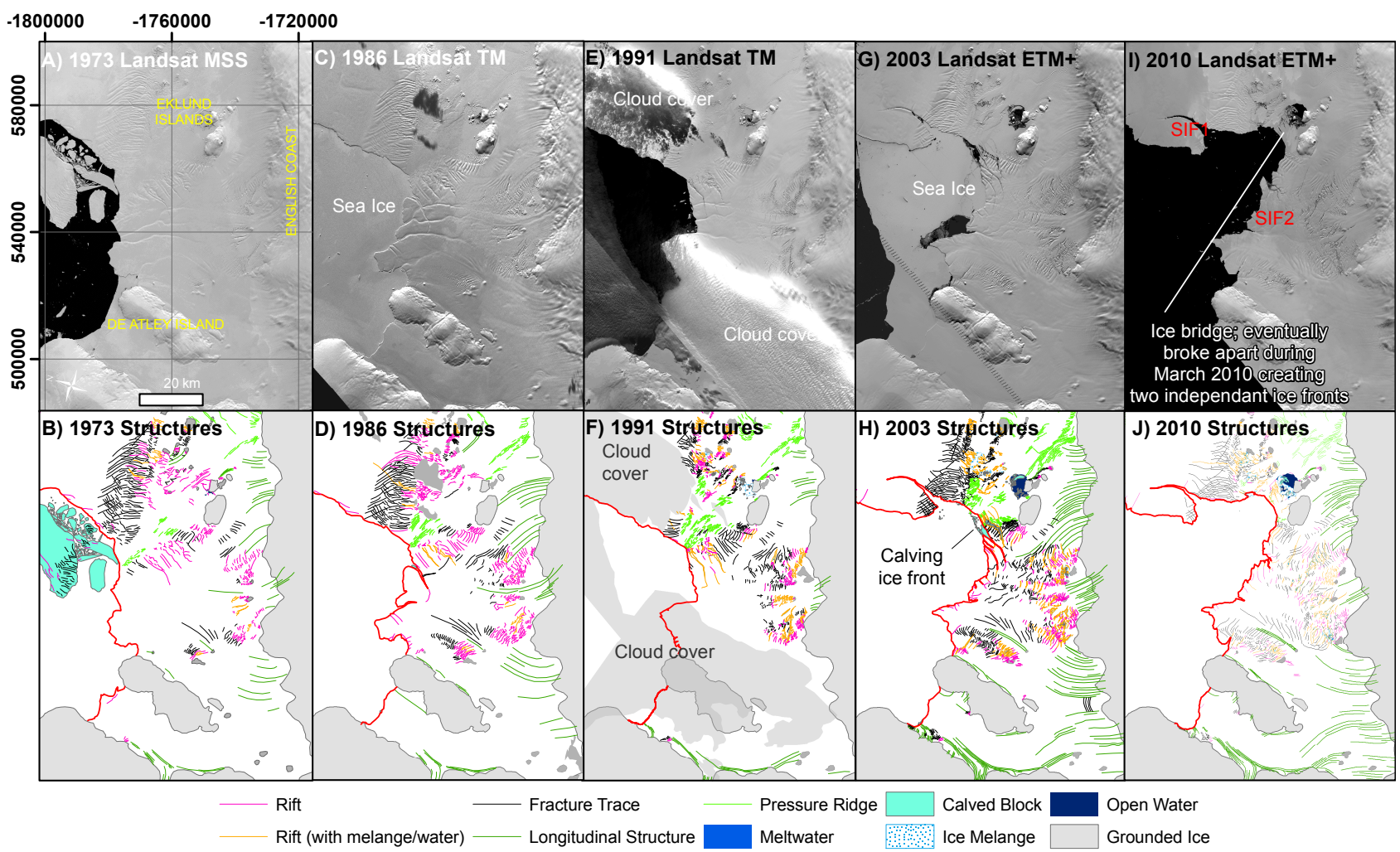

Fig. 5. Structural evolution at the south ice front illustrating widespread rifting lee side of the Eklund Islands and the English Coast. Increased rifting is apparent between the Eklund Islands and De Atley Island. During March 2010, a weak ice bridge north of the largest Eklund Island broke apart leaving two independent ice fronts (SIF1 and SIF2).

generated by a hydrostatic rebalancing of the floating shelf ice, thus leading to a lowering of the surface as seen on Larsen C Ice Shelf (e.g. Luckman et al., 2012; McGrath et al., 2012). Whilst we do not attempt to decipher between surface and basally governed fracture mechanisms, we recognise that the formation of basal crevasses may also play an important role in the structural glaciological conditions and the evolution of the ice shelf over time.

Furthermore, an area of open water lee side of the Eklund Islands, first apparent in 1991 (Fig. 5f), increased in size from 1991 to 2010 with the ice bridge that connected SIF1 and SIF2 eventually breaking away during March 2010, leaving two independent ice fronts terminating into the Ronne Entrance.

\subsection{Variations in ice-front flow}

\subsubsection{North ice front}

The flow of the north ice front is principally controlled by Riley Glacier (Fig. 6). Between ca. 1989 and ca. 2007 the surface speed of ice derived from this particular glacier increased across the whole ice front as it retreated back upstream. During ca. 2007, surface speeds reached a maximum of $390 \pm 15 \mathrm{~m} \mathrm{a}^{-1}$ in the centre of the ice front, an increase of $\sim 214 \pm 38 \mathrm{~m} \mathrm{a}^{-1}$ from ca. 1989. The surface speed of all other glaciers entering the ice shelf towards the north ice front did not change significantly during any of the observed time periods.

\subsubsection{South ice fronts}

The south ice fronts (Fig. 7) are characterised by complex dynamics due to the presence of the Eklund Islands that reduce the flow speeds of GVIIS. From Monteverdi Peninsula to the Eklund Islands, surface speeds are typically less than $390 \mathrm{~m} \mathrm{a}^{-1}$ and are driven by tributary glaciers some $150 \mathrm{~km}$ upstream. Our results indicate that flow speeds here did not significantly increase or decrease between ca. 1989 and ca. 2010. The greatest changes are observed between the Eklund Islands and De Atley Island, fed by four major glaciers (GT04-GT07), with acceleration of up to $340 \pm 38 \mathrm{~m} \mathrm{a}^{-1}$ measured at the ice front. This increase in surface speed is apparent from the grounding zone of GT04, GT05, GT06 and GT07 towards the ice front. During ca. 2010 the maximum recorded velocity in the centre of SIF2 was $796 \mathrm{~m} \mathrm{a}^{-1}$. 


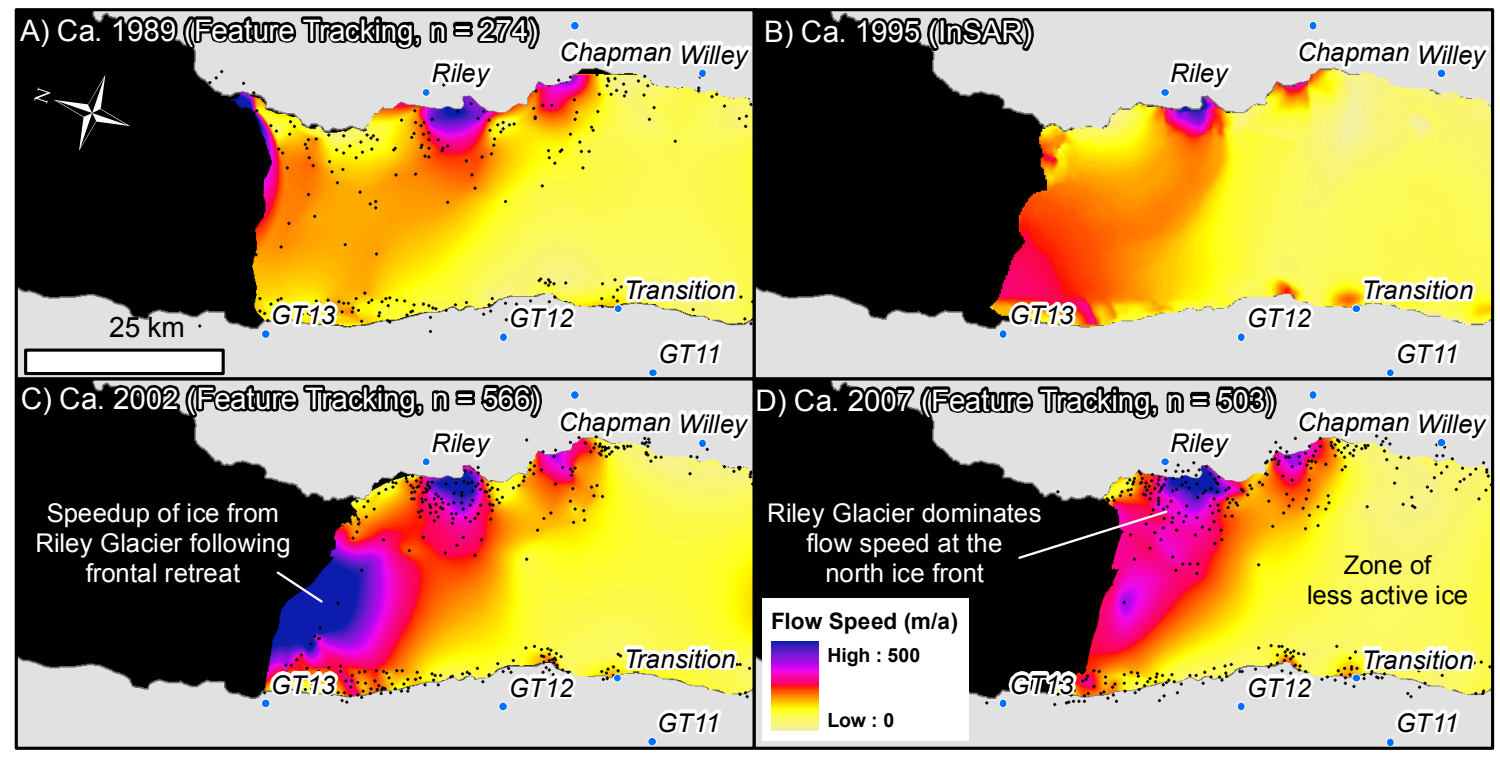

Fig. 6. Surface-speed calculations at the north ice front for ca. 1989 (A), ca. 1995 (B), ca. 2002 (C) and ca. 2007 (D) illustrating an increase in flow speed of glacier ice flowing from Riley Glacier as the ice front retreated upstream. Less active ice is apparent in each observation period that is inferred to be buttressed by the dominant flow from Riley Glacier at the ice front. Black dots represent the centre point of tracked features that were used to interpolate surface speeds. Uncertainties: (A) $\pm 30 \mathrm{~m} \mathrm{a}^{-1},(\mathbf{B}) \pm 25 \mathrm{~m} \mathrm{a}^{-1},(\mathbf{C}) 15 \pm \mathrm{m} \mathrm{a}^{-1},(\mathbf{D}) \pm 15 \mathrm{~m} \mathrm{a}^{-1}$.

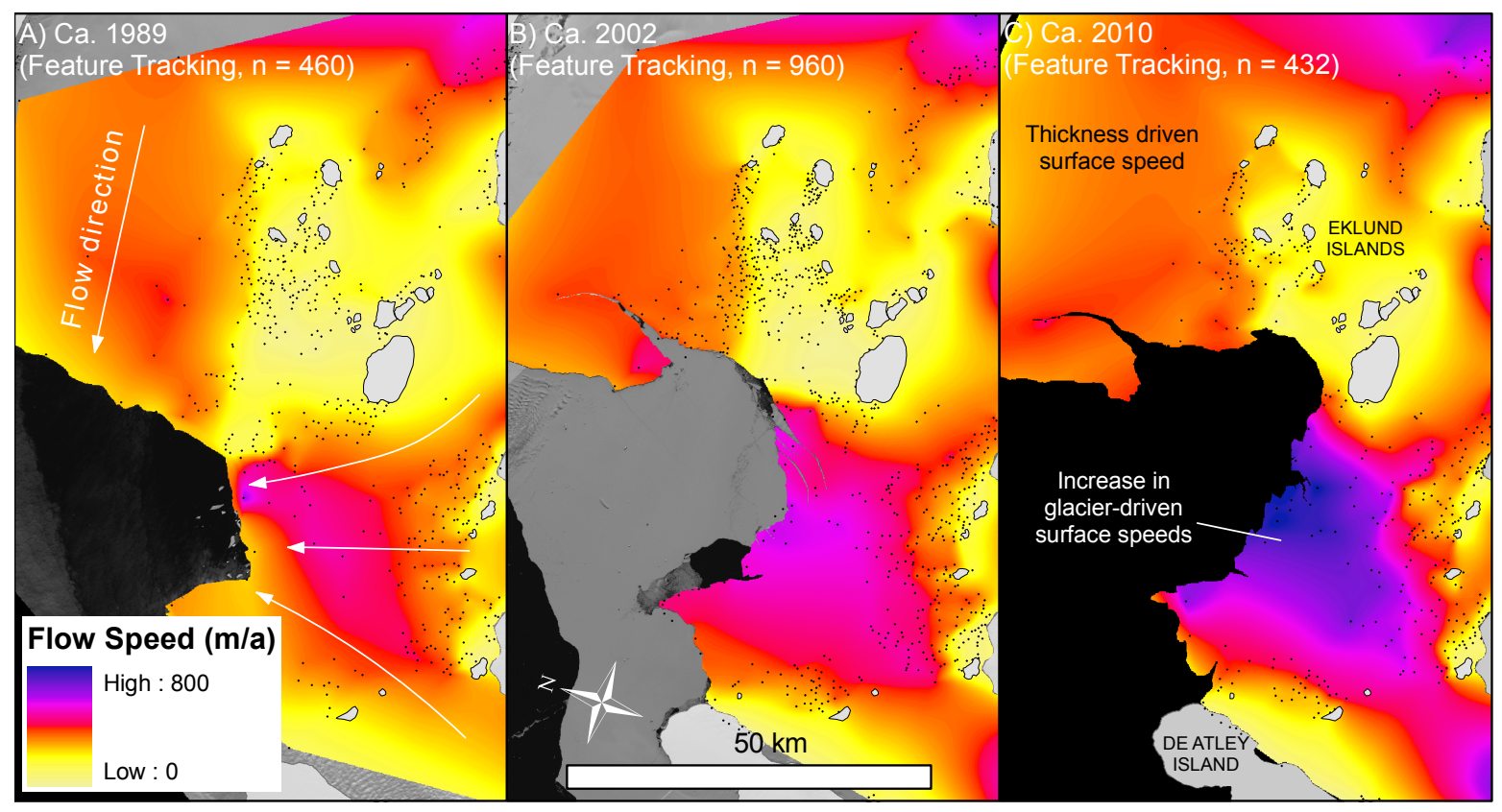

Fig. 7. Surface speed calculations at the south ice front for ca. 1989 (A), ca. 2002 (B) and ca. 2010 (C). There is a clear increase in speed between the Eklund Islands and De Atley Island from ca. 1989 to ca. 2010, whilst thickness-driven flow (Humbert, 2007) north of the Eklund Islands does not change over time. Black dots represent the centre point of tracked features used for interpolating surface speeds. Uncertainties: (A) $\pm 30 \mathrm{~m} \mathrm{a}^{-1}$, (B) $\pm 15 \mathrm{~m} \mathrm{a}^{-1}$, (C) $15 \pm \mathrm{m} \mathrm{a}^{-1}$. 


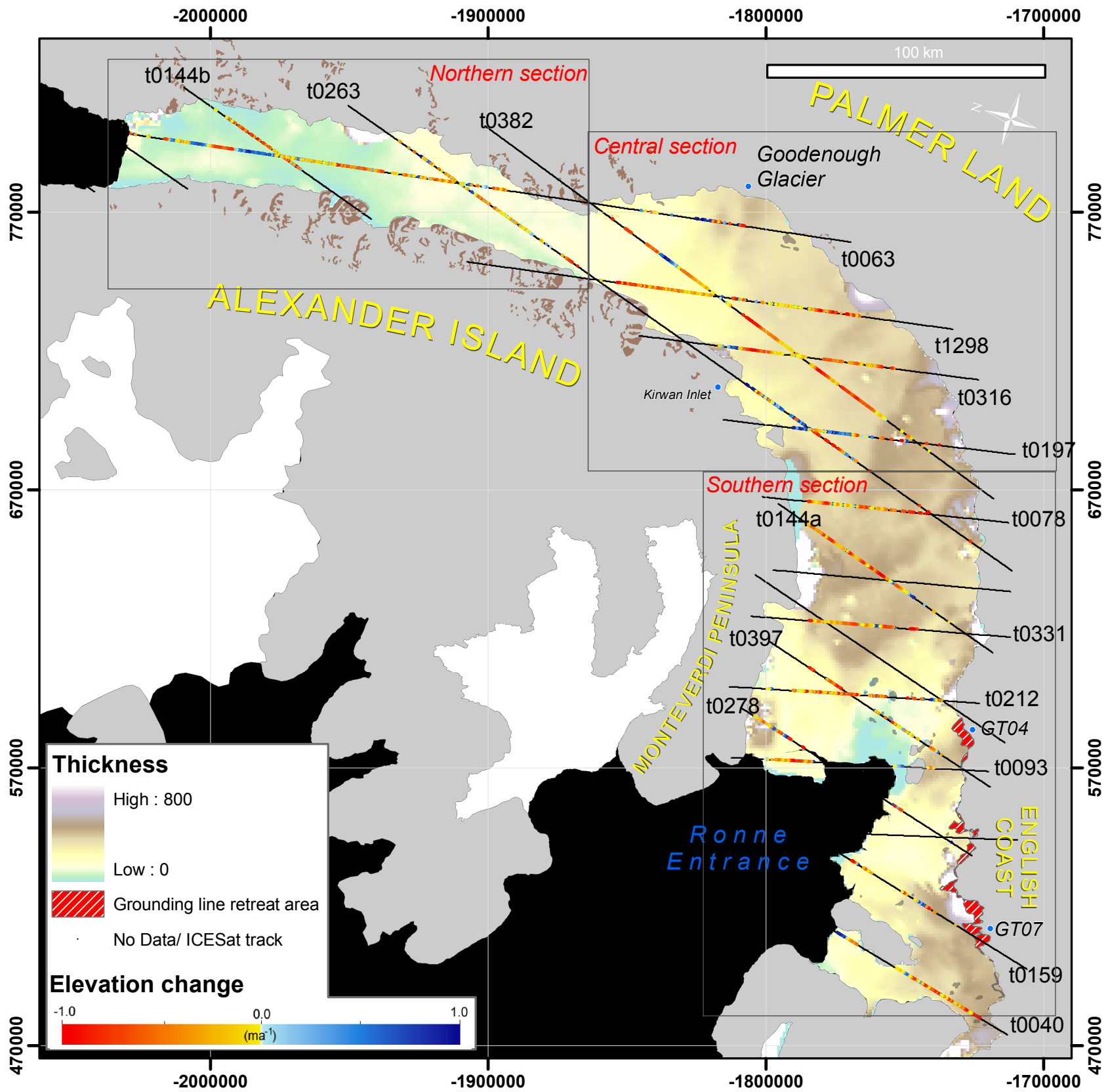

Fig. 8. Surface elevation changes from ICESat's GLAS repeat measurements (see Table 3 for mean elevation change for each track). A weak, non-significant thinning signal is recorded within the northern section, with distinct pockets of positive elevation change noted towards the ice front. The central section illustrates complex patterns of elevation change, with the greatest losses calculated where ice-shelf draft is thickest. In the southern section, widespread and significant negative elevation change has been calculated, coupled with an observed retreat of the grounding zone between GT04 and GT07 along the English Coast. Ice-thickness data sourced from Griggs and Bamber (2011).

\subsection{Surface-elevation changes}

Surface elevation change in the northern section of GVIIS was calculated over three tracks with a total of 1017 repeat measurements examined (Fig. 8, Table 3). A non-significant (less than our uncertainty) negative change is observed in the data, with pockets of positive elevation change interspersed between areas of surface lowering; there are few distinct patterns in the dataset.

In the central section, six GLAS tracks cut across GVIIS, with 1657 repeat measurements analysed (Fig. 8, Table 3). A complex pattern of surface-elevation changes is observed, with positive changes noted at the input of Goodenough Glacier (track 0063) and towards the northern extents of 
Table 3. Mean elevation change for each ICESat GLAS track over GVIIS. See Fig. 8 for location.

\begin{tabular}{lccc}
\hline Track & Laser campaigns & Observation period & Mean annual change $\left(\mathrm{ma}^{-1}\right)$ \\
\hline t0063 & $2 \mathrm{a}-3 \mathrm{k}$ & $25 / 10 / 03-13 / 10 / 08$ & $-0.033( \pm 0.045)$ \\
t0144b & $3 \mathrm{~d}-3 \mathrm{i}$ & $04 / 11 / 05-17 / 10 / 07$ & $-0.050( \pm 0.038)$ \\
t1298 & $3 \mathrm{c}-3 \mathrm{f}$ & $21 / 05 / 05-25 / 05 / 06$ & $-0.127( \pm 0.167)$ \\
t0316 & $3 \mathrm{a}-3 \mathrm{i}$ & $30 / 10 / 04-28 / 10 / 07$ & $-0.246( \pm 0.089)$ \\
t0197 & $2 \mathrm{a}-3 \mathrm{i}$ & $03 / 11 / 03-20 / 10 / 07$ & $+0.049( \pm 0.089)$ \\
t0263 & $3 \mathrm{a}-3 \mathrm{i}$ & $26 / 10 / 04-25 / 10 / 07$ & $-0.007( \pm 0.045)$ \\
t0078 & $2 \mathrm{a}-3 \mathrm{k}$ & $26 / 10 / 03-14 / 10 / 08$ & $-0.193( \pm 0.089)$ \\
t0144a & $2 \mathrm{a}-3 \mathrm{i}$ & $30 / 10 / 03-17 / 10 / 07$ & $-0.287( \pm 0.038)$ \\
t0331 & $2 \mathrm{~b}-3 \mathrm{e}$ & $18 / 03 / 04-24 / 03 / 06$ & $-0.127( \pm 0.097)$ \\
t0397 & $3 \mathrm{a}-3 \mathrm{~d}$ & $04 / 11 / 04-21 / 11 / 05$ & $-0.587( \pm 0.089)$ \\
t0212 & $3 \mathrm{c}-3 \mathrm{f}$ & $08 / 06 / 05-12 / 06 / 06$ & $-0.115( \pm 0.089)$ \\
t0093 & $2 \mathrm{a}-3 \mathrm{k}$ & $27 / 10 / 03-15 / 10 / 08$ & $-0.249( \pm 0.098)$ \\
t0278 & $3 \mathrm{~d}-3 \mathrm{i}$ & $13 / 11 / 05-26 / 10 / 07$ & $-0.079( \pm 0.097)$ \\
t0159 & $3 \mathrm{a}-3 \mathrm{i}$ & $19 / 10 / 04-18 / 10 / 07$ & $-0.215( \pm 0.089)$ \\
t0040 & $2 \mathrm{a}-3 \mathrm{k}$ & $23 / 10 / 03-11 / 10 / 08$ & $-0.267( \pm 0.098)$ \\
\hline
\end{tabular}

tracks 0197 and 0263, near the input of Kirwen Inlet. Large negative elevation changes are recorded along track 0382 , which dissects central region of the ice shelf. Tracks 1298 and 0316 both illustrate ice-shelf-wide negative surface elevation changes.

Widespread negative surface-elevation change has also been calculated over 1642 repeat measurements in the southern section, interspersed with localised pockets of positive elevation changes (Fig. 8, Table 3). Due to rifting towards the south ice front, however, the GLAS dataset was heavily filtered, and therefore direct measurements of surface elevation changes are incomplete towards the English Coast and around the Eklund Islands.

\subsection{Grounding-zone retreat}

The analysis of sequential satellite images highlighted a gradual retreat of the grounding zone between 1973 and 2010 at the southern extent of GVIIS along the English Coast of Palmer Land (Fig. 8). In total, $172 \mathrm{~km}^{2}$ of ice-shelf area was affected by the retreating grounding zone over a $90 \mathrm{~km}$ distance between the eastern boundary of GT04 and the western boundary of GT07. There is no evidence of grounding zone retreat elsewhere along either Palmer Land or Monteverdi Peninsula, although the reducing surface visibility of various ice rises also points to a retreating grounding zone around the Eklund Islands from which is it inferred that the southern region has experienced widespread thinning since at least 1973.

\section{Discussion}

\subsection{Glaciological controls on GVIIS retreat}

\subsubsection{Northern extent of GVIIS}

Smith et al. (2007) and Cook and Vaughan (2010) show a north ice-front position similar to that of the 1974 margin presented in this study, but also illustrate a frontal advance between 1947 and 1960, followed by sustained retreat. The conditions of the ice front prior to 1947 are uncertain, although Fleming et al. (1938) reported that sea-ice-filled rifts occupied the northern sections of George VI Sound, possibly extending to Cape Jeremy (Doake, 1982) (Fig. 1). If these early observations are indicative of the former extent, then the amount of ice lost from GVIIS between 1936 and 1974 is comparable ( $\sim 40 \mathrm{~km}$ linear along centreline) to the loss recorded between 1974 and 2010 ( 41 km linear along centreline). The rate of retreat over these two longer observation periods ( $1.0 \mathrm{~km} \mathrm{a}^{-1}$ and $1.1 \mathrm{~km} \mathrm{a}^{-1}$, respectively) is remarkably similar and perhaps illustrates the periodic large-scale breakup of the northern ice front.

Our results illustrate a two-phase retreat of the north ice front from 1974 to 2010, with one large breakup event (1974-1979) followed by several smaller phases (19792010). The north ice front during 1974 was heavily rifted across almost the entire channel width between Alexander Island and Palmer Land, extending back upstream for $\sim 40 \mathrm{~km}$ to the northern boundary of Riley Glacier. The regularity of rifts in this zone of relatively slow-moving, inactive ice suggests that these features had gradually developed, forming at the grounding zone through either flow-induced longitudinal extension or bending stresses caused by tidal motion. They may also or represent the surface expression of basal crevasses as recently investigated on Larsen C Ice Shelf 


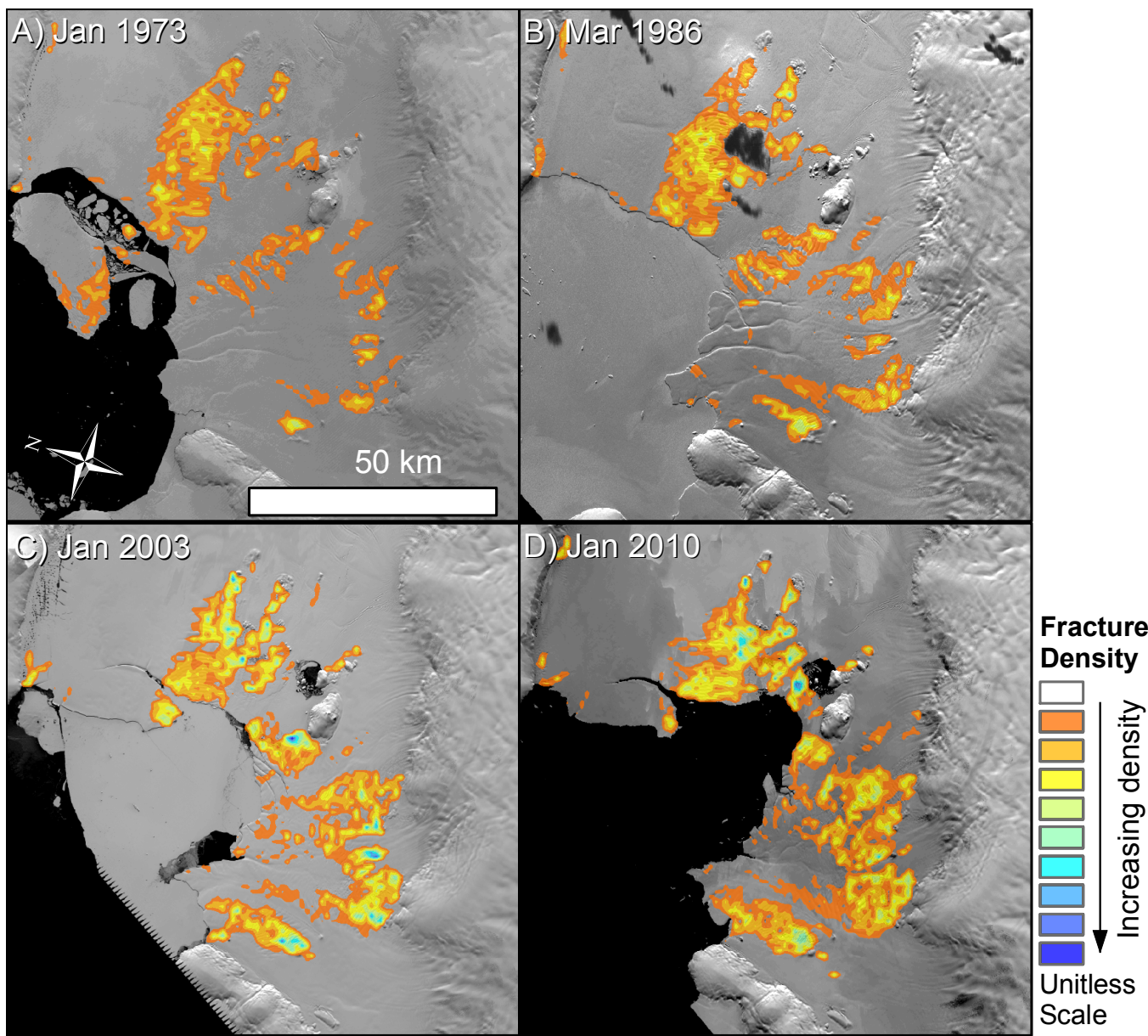

Fig. 9. Fracture trace and rift distribution and density (see Fig. 5 for structural maps) over four time periods ((A) 1973, (B) 1986, (C) 2003 and (D) 2010). Increasing density is noted both north and west of the Eklund Islands in areas where widespread thinning has been shown. Increased rifting between the Eklund Islands and De Atley Island is also linked to increasing ice-shelf flow speeds recorded between ca. 1989 and ca. 2010 (Fig. 7).

(e.g. Luckman et al., 2012; McGrath et al., 2012). However formed, the rifts propagated across the ice shelf towards the north ice front (Fig. 4b). Further rifting between 1996 and 2001 eventually led to a large calving event during January 2010, although rift development this time developed from the western margin near Alexander Island rather than from Palmer Land. Most of the retreat at the north ice front was thus governed by preconditioned and long-standing active rifts, developed well in advance of actual calving. Indeed, the eventual 1979 and 1989 ice fronts were observed as rifts in 1974 Landsat MSS imagery (Fig. 4), thus emphasising the long-term development of the retreat process the north ice front. As of March 2010, no ice-shelf-wide rifts existed in this region, thus no immediate large-scale calving is anticipated.

The retreat recorded between 1974 and 1979 in the northern region occurred in an area devoid of significant glacier input, and thus we suggest that the retreat rate of the north ice front is largely controlled by its dynamic configuration.
Elsewhere on GVIIS, areas of rifted ice are observed between coalescing flow units (Fig. 2). These areas tend to exhibit longitudinal extension at the grounding zone, causing initial fracturing, with stress regimes becoming more compressive with increased distance from the ice-shelf margin due to the coalescing of ice-flow units. Thus, the switch from an initial tensile regime to a compressive stress regime within a limited spatial extent restricts fracture and rift propagation and indeed prompts the sealing of fractures. North of Riley Glacier, coalescence with a second tributary glacier did not occur, and thus ice did not undergo longitudinal compression after initial fracturing. It is proposed that as a result of this dynamic configuration, fractures emanating from Riley Glacier at the grounding zone are able to spread transversely across the ice shelf as it flows towards the northern ice front with little or no resistance, thus preconditioning the northern ice front for the large-scale retreat observed. 


\subsection{Southern extent of GVIIS}

At the south ice fronts, Smith et al. (2007) indicate a continued retreat since 1947, with substantial ice loss between ca. 1967 and 1973. From observations in this study, only a small portion of the south ice front (adjacent to Monteverdi Peninsula) was found to be advancing, yet even this area appears to show a repeated advance/calving regime, with further calving anticipated along the ice-front rift that has progressively developed since ca. 1996 (Fig. 5).

The overwhelming pattern of the south ice front is that of steady retreat, concentrated in the centre of the ice front. It is inferred from visual assessment of 1973 Landsat imagery that this region has a lower surface elevation lee side of these ice rises. Thickness calculations from radar altimetry (RA) elevation data (e.g. Griggs and Bamber, 2011) confirm this (Fig. 8). To the north of the Eklund Islands the ice shelf is thicker, but heavily fractured - as it is between the Eklund Islands and De Atley Island.

The presence of the Eklund Islands towards the south ice front is therefore a critical component in the retreat characteristics of GVIIS. First, their presence causes regular rifting of the ice shelf as it flows around (or over) such features due to a shift from high-compressional stresses upstream to tensile stresses downstream. Second, the composition of shelfice, lee side of ice rises and ice rumples has elsewhere been shown to have a higher concentration of warmer, marinederived ice, accreted in basal cavities and incorporated into the ice shelf through the resealing of rifts with flow (Fricker et al., 2001; Khazendar and Jenkins, 2003). Whilst considered to be less brittle than meteoric ice (Lui and Miller, 1979; Jansen et al., 2010), the warmer (Vieli et al., 2007), marinederived ice is more susceptible to oceanographic variations (Fricker et al., 2001). Third, the Eklund Islands have a profound effect on regional surface speeds and thus the supply of ice to this region. Feature-tracking measurements from each of the observation periods reveals substantially slower flow speeds down-ice of the Eklund Islands than those observed outside of this region; the ice rises/rumples essentially act as a buttress to flow. Furthermore, during 1973, the southern ice front arguably satisfied the criteria of Doake et al. (1998) for irreversible retreat, displaying a largely concave profile. A combination of these factors made large portions of the south ice front pre-conditioned for iceberg calving and continued retreat as observed between 1973 and January 2010.

Towards the central and southern extents of GVIIS, a stronger surface-lowering signal is measured from which widespread ice-shelf thinning is inferred. In the central region in particular, the ice-shelf draft of GVIIS reaches much greater depths than at any other point in George VI Sound, and thus it may be subjected to warmer waters that tend to exist closer to the sea bed (Jenkins and Jacobs, 2008; Holland et al., 2010). Thus, the thickest parts of GVIIS are subjected to high rates of basal melt and lower rates of basal accretion, which results in a net loss of ice through a vertical column.
It appears that an increase in the rate of retreat of the south margin between 1991 and 1996 immediately follows a strong vertical mixing within the Bellingshausen Sea between 1989 and 1992 (Holland et al., 2010). This pattern in also reflected in the timing of ice front retreat of Bach and Stange Ice Shelves (Holt, 2012) that promotes the idea that short-term, intermittent oceanic variation can impact on the glaciological conditions of ice shelves. Subsequently, a warming Ronne Entrance portion of the Bellingshausen Sea coupled with the inferred high concentrations of marine-derived ice lee side of the Eklund Islands and a structurally weak ice shelf preconditioned the south ice fronts for further retreat. Therefore, we suggest that the south ice front in particular responds to changes in ice thickness caused by oceanic temperature variation.

\subsection{Glaciological response of GVIIS to ice-front retreat}

As a result of ice-front recession, the northern region of GVIIS became increasingly dominated by the dynamics of Riley Glacier. Feature tracking measurements from ca. 1989, ca. 2002 and ca. 2007, coupled with InSAR velocities (ca. 1995) clearly illustrate an increase in flow speed of Riley Glacier over time. Elsewhere on the AP it has been demonstrated that the removal of an ice-shelf system results in an increase in velocity of former tributary glaciers (De Angelis and Skvarca, 2003; Dupont and Alley, 2005; Glasser et al., 2011; Berthier et al., 2012), and whilst Riley Glacier still contributes to the mass of GVIIS, the continued retreat of the north ice front has effectively removed a buttress, reducing back stresses and subsequently permitted an increase in surface velocity at the northern margin. Further upstream, flow speeds of Skinner, Chapman, GT12 and Transition Glaciers do not show an increase or decrease over time, and thus further illustrate the dominance and controlling nature of Riley Glacier on the dynamic regime of the north ice front.

At the south ice front we propose that the removal of buttressing ice between 1973 and 2010 led to increased longitudinal extension through the reduction of back stresses within the ice shelf. This is clearly reflected in feature tracking measurements between ca. 1989, ca. 2002 and ca. 2010, with ever-increasing surface speeds between the Eklund Islands and De Atley Island over time. Indeed, between the Eklund Island and De Atley Island, localised flow speed had almost doubled from $\sim 380 \pm 30 \mathrm{~m} \mathrm{a}^{-1}$ to $\sim 780 \pm 15 \mathrm{~m} \mathrm{a}^{-1}$. These increases appear to be driven by two different processes: (1) increased extensional pulling from the ice front, and (2) acceleration of GT07 from its grounding zone. There is a clear link between the increase in flow speed over time and the increased distribution and extent of rifts and fracture traces that make this particular area structurally and dynamically weak.

Between Monteverdi Peninsula and the Eklund Islands, however, an advance of the ice front is driven by tributary glaciers some $150 \mathrm{~km}$ back upstream. We measure no 
significant (greater than our uncertainty) variation in flow speeds over time, and as a result, the area between the Eklund Islands and Monteverdi Peninsula appears to be more stable and less responsive to observed environmental and glaciological changes.

\subsection{The future stability of GVIIS}

\subsubsection{The north ice front}

The retreat history of the north ice front since ca. 1940 alludes to periodic large-scale breakup of heavily fractured ice that stretches for some distance back upstream from the ice front. The multidecadal recurrence interval over which rifts develop and propagate allows the anticipation of ice-loss extent well in advance of actual calving. Thus, based on these historical observations, no immediate large-scale calving is expected from the north ice front as few rifts currently exist. Iceberg calving will most likely be governed by regular but discreet calving at the ice front. However, the north ice front is not in a steady state and has changed considerably over the $\sim 40 \mathrm{yr}$ period observed here; it is anticipated that recession will continue in response to environmental changes.

Our data illustrate that the structural regime at the north ice front is governed by the dynamics of individual tributary glaciers that flow from Palmer Land. It has been shown that where there is a lack of longitudinal and transverse compression (due to the absence of flow-unit confluence), rifts are capable of propagating across the ice shelf, along which largescale calving is initiated. The short bursts of rapid retreat are linked to the breakup of comparatively "less active" zones of shelf ice, with retreat rate much less where the ice front is directly supplied by fast-flowing "active" ice. The latter situation currently exists (Fig. 6), with iceberg calving and retreat rate governed by the dynamics of Riley Glacier. The current flow configuration south of Riley Glacier has a comparatively slower, less active dynamic regime absent of significant glacier input. We propose that this area is currently exposed to high back stresses by the presence of Riley Glacier, limiting longitudinal extension that ultimately restricts fracturing. Continued recession of the north ice front (over any timescale) would reduce the back stresses upstream and encourage fracturing of shelf ice across an approximate area of $1200 \mathrm{~km}^{2}$ towards Millett Glacier, potentially rendering this entire section weak and susceptible to large-scale retreat, as observed between 1974 and 1979.

Surface melting on GVIIS in the northern region has been ongoing since at least 1940 (Stephenson and Fleming, 1940), yet the compressive flow regime of the ice shelf has limited the effect of surface meltwater on its structural stability. Furthermore, the northern limit of surface meltwater has always been south of the ice front, but in recent years it has been shown to expand towards a retreating northern margin. As a result, a combination of structural weakening (longitudinal extension), abundant meltwater and intensifying surface- melt brought on by warmer temperatures (e.g. Vaughan et al. 2003) and a lengthening melt season (Torinesi et al., 2003) creates an environment susceptible to further atmospheric warming and possibly hydro-fracture-driven shelf retreat.

Recent modelling studies (e.g. Holland et al., 2010) have suggested that the rate of basal melt in the northern region increased from $\sim 1.8 \mathrm{~m} \mathrm{a}^{-1}$ to $\sim 2.0 \mathrm{~m} \mathrm{a}^{-1}$ since 1980 . Whilst comparatively high relative to the other ice shelves on the West Antarctic Peninsula, basal melt rate remains marginally less than the $2.1 \mathrm{~m} \mathrm{a}^{-1}$ rate suggested by Potter et al. (1984) in order for the ice shelf to remain in equilibrium. The northern region of GVIIS is therefore not losing sufficient mass from its base to instigate widespread thinning. Whilst surface melting is evident for prolonged periods of the austral summer, the absence of sufficient surface drainage means that meltwater refreezes on the surface of the ice shelf and therefore the actual mass lost is considered negligible. As a result, the northern section of GVIIS is perhaps less susceptible to ice-shelf thinning, although Fricker and Padman (2012) comment that surface lowering terminated on Wilkins Ice Shelf approximately $8 \mathrm{yr}$ prior to the two most recent breakup phases in 2008 and 2009, and thus a lack of vertical change may not necessarily point to a stable ice shelf. The northern region, however, is susceptible to regular surface melting regardless of whether mass is lost from the ice shelf or not. The stabilising characteristic is its unusual dynamic regime that will ultimately control the spatial and temporal retreat/ breakup patterns.

\subsubsection{The south ice fronts}

The south ice fronts have seen by far the greatest change in recent decades as a response to climatic and oceanic variability. Prior to March 2010, this margin underwent sustained retreat, concentrated in the central portion that we inferred to be both thin and have a high concentration of marineaccreted ice. This sustained ice loss (horizontal and vertical) has rendered large portions of the southern margins structurally weak and prone to iceberg calving along preconditioned rifts. The removal of the central portion of the ice front consequently split it into two individual ice fronts that, even despite their close proximity, have distinctly different glaciological regimes.

The negative surface-elevation changes observed to date is linked to increasing basal melting as a result of a warming ocean (Holland et al., 2010; Pritchard et al., 2012). Assuming that this warming will continue, the southern region of GVIIS is particularly vulnerable to heightened retreat as a result of increased basal melting and a reduction of in situ basal accretion.

The stability of SIF1 is governed by its frontal geometry and thickness-driven velocity from further upstream, particularly towards Monteverdi Peninsula. This portion has historically shown prolonged periods of advance followed by large-scale calving, and indeed, calving is anticipated in the 
coming years along a well-developed rift. Even after this expected loss of ice, the ice front would remain relatively stable. Being convex over much of its length, it is expected that it would also maintain a similar speed as it has done in previous decades as it is seemingly non-responsive to retreat patterns; its dynamics are driven by its thickness gradient between the ice front and its tributary grounding lines.

Towards the Eklund Islands, SIF1 is structurally weak. Large areas are heavily rifted, and the recent retreat history illustrates that these are most susceptible to further ice loss, particularly as increasing basal melting and reduced basal accretion (Holland et al., 2010) will limit basal accumulation. Furthermore, the ice melange that fills the rifts is likely to reduce, and with it any resistance to further propagation (Bassis et al., 2005). Within the next decade it is probable that the ice directly in front of these ice rises will have disappeared, leaving the ice shelf pinned behind them.

Ice feeding SIF2 has seen the greatest dynamic and structural changes and indeed is most likely to undergo further retreat. In particular, it remains vulnerable to oceanic warming and intermittent vertical mixing of CDW, as noted by Holland et al. (2010). The positioning of several ice rises close to the grounding zone, in addition to those further downstream, almost certainly create basal cavities, that not only results in thinner regions of shelf ice, but also encourage basal accretion of marine ice. As a result, ice feeding SIF2 is likely to have a high concentration of marine-derived ice that naturally results in these thinner areas being more susceptible to oceanic variation.

Furthermore, the distribution rifts and fracture traces has increased (Fig. 9), many being filled with an ice melange that elsewhere has been shown to limit further propagation (e.g. Bassis et al., 2005). Even within the last decade, the number of open rifts with visible water has increased, and as this region is outside of that which is subjected to abundant surface melting, it is clear that this is open sea water. A warming environment (climatic and oceanic) has effectively begun to remove the stabilising ice melange in these rifts. As a result, future widening of these rifts is almost certain to occur as they progress through the ice shelf towards the front, increasing the rate of retreat and also increasing the likelihood of rapid breakup phases.

\section{Summary and conclusions}

Our analysis of the glaciological evolution of GVIIS has revealed its vulnerability to ongoing environmental change in the AP. The north and south ice fronts occupy two very different environmental settings and thus the glaciological controls of, and responses of, ice-front retreat vary considerably. Analysis of optical, radar and laser altimeter remote sensing datasets has led to the following conclusions:

1. Spatial and temporal retreat patterns observed at the north ice front between 1974-present were controlled by longstanding and widespread ice-shelf rifts. Rapid breakup (1974-1979) was followed by steady retreat (1979-present) along rifts near the ice front, and coupled with a concave ice front profile; the northern region was arguably preconditioned for sustained retreat. At present, there are few channel-wide rifts that have previously hastened calving from the north ice front, and thus we do not anticipate immediate large-scale retreat. However, we do expect continued recession through discreet calving events, which, coupled with a northward expansion of the meltwater limit, raises the possibility of hydro-fracture-driven retreat at this northern margin.

2. The retreat rate recorded at the south ice fronts was steadier than the north ice front, although there is evidence of increased retreat rate following periods of warm-water upwelling in the Bellingshausen Sea. Iceberg calving at the south ice front was focused in areas where the shelf was inferred to be thinner, was heavily fractured, and where high concentrations of marineaccreted ice were inferred. We suggest that the southern ice front was also preconditioned for retreat between 1973 and 2010, although at present both SIF1 and SIF2 have more stable, convex ice-front geometries.

3. Surface velocities at the north and south ice fronts increased over time. In both circumstances this has been attributed to reduced back stresses within the ice shelf that permitted enhanced longitudinal extension. Between the Eklund Islands and De Atley Island in particular, this occurred simultaneously with increased rifting that has rendered this area structurally weak. The dynamics of the north ice front are at present dominated by Riley Glacier, which buttresses shelf ice further upstream; the longevity of Riley Glacier thus governs the glaciological responses of the rest of the ice-shelf system in the northern region.

4. In the central and southern regions of GVIIS widespread surface lowering was recorded. We link this to enhanced basal melting rather than surface ablation and thus conclude that the southern extents of GVIIS are more susceptible to ongoing oceanic warming. Coupled with grounding line retreat, we infer significant iceshelf thinning.

5. Rapid disintegration of GVIIS is not anticipated; however, our investigation has shown that significant glaciological changes have taken place south of the proposed atmospheric limit of ice-shelf viability, and that the southern end of the ice-shelf system is more vulnerable to oceanic warming than atmospheric change.

Supplementary material related to this article is available online at: http://www.the-cryosphere.net/7/797/ 2013/tc-7-797-2013-supplement..pdf. 
Acknowledgements. We are grateful to Helen Fricker for her support during the pre-processing and analysis of the GLAS surface elevation data. We also offer our thanks to M. Pelto, T. Scambos and two anonymous referees for their concise and constructive comments. ERS 1/2 SAR data was accessed through Category 1 Proposal C1P.6227.

Edited by: I. M. Howat

\section{References}

Antarctic Place-names Committee: http://www.Antarctica.ac.uk/ apc/index.html, last access: 01-01-2010, 2009.

Bassis, J. N., Coleman, R., Fricker, H. A., and Minster, J. B.: Episodic propagation of a rift on the Amery Ice Shelf, East Antarctica, Geophys. Res. Lett., 32, L06502, doi:10.1029/2004g1022048, 2005.

Bentley, M. J., Hodgson, D. A., Sugden, D. E., Roberts, S. J., Smith, J. A., Leng, M. J., and Bryant, C.: Early Holocene retreat of the George VI Ice Shelf, Antarctic Peninsula, Geology, 33, 173-176, 2005.

Bentley, M. J., Johnson, J. S., Hodgson, D. A., Dunai, T., Freeman, S. P. H. T., and Cofaigh, C.: Rapid deglaciation of Marguerite Bay, western Antarctic Peninsula in the early Holocene, Quaternary Sci. Rev., 30, 3338-3349, 2011.

Berthier, E., Scambos, T. A., and Shuman, C. A.: Mass loss of Larsen B tributary glaciers (Antarctic Peninsula) unabated since 2002, Geophys. Res. Lett., 39, L13501, doi:10.1029/2012gl051755, 2012.

Bindschadler, R., Scambos, T. A., Rott, H., Skvarca, P., and Vornberger, P.: Ice dolines on Larsen Ice Shelf, Antarctica, Ann Glaciol, 34, 283-290, 2002.

Bindschadler, R. A., Vaughan, D. G., and Vornberger, P.: Variability of basal melt beneath the Pine Island Glacier Ice Shelf, west Antarctica, J. Glaciol., 57, 581-595, 2011.

Braun, M., Humbert, A., and Moll, A.: Changes of Wilkins Ice Shelf over the past 15 years and inferences on its stability, The Cryosphere, 3, 41-56, doi:10.5194/tc-3-41-2009, 2009.

Brenner, A. C., DiMarzio, J. P., and Zwally, H. J.: Precision and accuracy of satellite radar and laser altimeter data over the continental ice sheets, IEEE T Geosci Remote, 45, 321-331, doi:10.1109/tgrs.2006.887172, 2007.

Brunt, K., Fricker, H. A., Padman, L., Scambos, T. A., and O’Neel, S.: Mapping the grounding zone of the Ross Ice Shelf, Antarctica, using ICESat laser altimetry, Ann Glaciol, 51, 71-79, 2010.

Brunt, K. M., Okal, E. A., and MacAyeal, D. R.: Antarctic ice-shelf calving triggered by the Honshu (Japan) earthquake and tsunami, March 2011, J. Glaciol., 57, 785-788, 2011.

Collins, L. F. and McCrae, I. R.: Creep buckling of ice shelves and the formation of pressure rollers, J. Glaciol., 31, 242-252, 1985.

Cook, A. J. and Vaughan, D. G.: Overview of areal changes of the ice shelves on the Antarctic Peninsula over the past 50 years, The Cryosphere, 4, 77-98, doi:10.5194/tc-4-77-2010, 2010.

Cooper, A. P. R.: Historical observations of Prince Gustav Ice Shelf, Polar Rec, 33, 285-294, 1997.

Corr, H. F. J., Jenkins, A., Nicholls, K. W., and Doake, C. S. M.: Precise measurement of changes in ice-shelf thickness by phase- sensitive radar to determine basal melt rates, Geophys. Res. Lett., 29, 1232, doi:10.1029/2001g1014618, 2002.

De Angelis, H. N. and Skvarca, P.: Glacier surge after ice shelf collapse, Science, 299, 1560-1562, 2003.

Dinniman, M. S., Klinck, J. M., and Hofmann, E. E.: Sensitivity of Circumpolar Deep Water transport and ice shelf basal melt along the west Antarctic Peninsula to changes in the winds, J. Climate, 25, 4799-4816, doi:10.1175/jcli-D-11-00307.1, 2012.

Doake, C. S. M.: State of balance of the ice sheet in the Antarctic Peninsula, Ann. Glaciol., 3, 77-82, 1982.

Doake, C. S. M. and Vaughan, D. G.: Rapid disintegration of the Wordie Ice Shelf in response to atmospheric warming, Nature, 350, 328-330, 1991.

Doake, C. S. M., Corr, H. F. J., Rott, H., Skvarca, P., and Young, N. W.: Breakup and conditions for stability of the northern Larsen Ice Shelf, Antarctica, Nature, 391, 778-780, 1998.

Dupont, T. K. and Alley, R. B.: Assessment of the importance of ice-shelf buttressing to ice-sheet flow, Geophys. Res. Lett., 32, L04503, doi:10.1029/2004g1022024, 2005.

Fleming, W. L. S., Stephenson, A., Roberts, B. B., and Bertram, G. C. L.: Notes on the scientific work of the British Graham Land Expedition, Geogr. J., 91, 508-532, 1938.

Fox, A. J. and Vaughan, D. G.: The retreat of Jones Ice Shelf, Antarctic Peninsula, J. Glaciol., 51, 555-560, 2005.

Fricker, H. A., Popov, S., Allison, I., and Young, N.: Distribution of marine ice beneath the Amery Ice Shelf, Geophys. Res. Lett., 28, 2241-2244, doi:10.1029/2000g1012461, 2001.

Fricker, H. A. and Padman, L.: Ice shelf grounding zone structure from ICESat laser altimetry, Geophys. Res. Lett., 33, L15502, doi:10.1029/2006g1026907, 2006.

Fricker, H. A. and Padman, L.: Thirty years of elevation change on Antarctic Peninsula Ice Shelves from multimission satellite radar altimetry, J. Geophys. Res., 117, C02026, doi:10.1029/2011JC007126, 2012.

Glasser, N. F. and Scambos, T. A.: A structural glaciological analysis of the 2002 Larsen B Ice-Shelf collapse., J. Glaciol., 54, 3-16, 2008.

Glasser, N. F., Kulessa, B., Luckman, A., Jansen, D., King, E. C., Sammonds, P. R., Scambos, T. A., and Jezek, K. C.: Surface structure and stability of the Larsen C Ice Shelf, Antarctic Peninsula, J. Glaciol., 55, 400-410, 2009.

Glasser, N. F. and Gudmundsson, G. H.: Longitudinal surface structures (flowstripes) on Antarctic glaciers, The Cryosphere, 6, 383 391, doi:10.5194/tc-6-383-2012, 2012.

Glasser, N. F., Scambos, T. A., Bohlander, J., Truffer, M., Pettit, E., and Davies, B. J.: From ice-shelf tributary to tidewater glacier: Continued rapid recession, acceleration and thinning of Rohss Glacier following the 1995 collapse of the Prince Gustav Ice Shelf, Antarctic Peninsula, J. Glaciol., 57, 397-406, doi:10.3189/002214311796905578, 2011.

Griggs, J. A. and Bamber, J. L.: Antarctic ice-shelf thickness from satellite radar altimetry, J. Glaciol., 57, 485-498, 2011.

Holland, P. R., Jenkins, A., and Holland, D. M.: Ice and ocean processes in the Bellingshausen Sea, Antarctica, J. Geophys. Res., 115, C05020, doi:10.1029/2008JC005219, 2010.

Holt, T. O.: An assessment of the stability of south-west Antarctic Peninsula Ice Shelves, PhD, Institute of Geography and Earth Sciences, Aberystwyth University, Aberystwyth, 440 pp., 2012. 
Horgan, H. J., Walker, R. T., Anandakrishnan, S., and Alley, R. B.: Surface elevation changes at the front of the Ross Ice Shelf: Implications for basal melting, J. Geophys. Res., 116, C02005, doi:10.1029/2010jc006192, 2011.

Hughes, T.: On the disintegration of ice shelves: The role of fracture, J. Glaciol., 29, 98-117, 1983.

Hulbe, C. L., Scambos, T. A., Youngberg, T., and Lamb, A. K.: Patterns of glacier response to disintegration of the Larsen B Ice Shelf, Antarctic Peninsula, Global Planet. Change, 63, 1-8, 2008.

Humbert, A.: Numerical simulations of the ice flow dynamics of George VI Ice Shelf, Antarctica, J. Glaciol., 53, 659-664, 2007.

Jansen, D., Kulessa, B., Sammonds, P. R., Luckman, A., King, E. C., and Glasser, N. F.: Present stability of the Larsen C Ice Shelf, Antarctic Peninsula, J. Glaciol., 56, 593-600, 2010.

Jenkins, A. and Jacobs, S.: Circulation and melting beneath George VI Ice Shelf, Antarctica, J. Geophys. Res., 113, C04013, doi:10.1029/2007jc004449, 2008.

Khazendar, A. and Jenkins, A.: A model of marine ice formation within Antarctic Ice Shelf rifts, J. Geophys. Res., 108, 3235, doi:10.1029/2002jc001673, 2003.

King, M. A. and Padman, L.: Accuracy assessment of ocean tide models around Antarctica, Geophys. Res. Lett., 32, L23608, doi:10.1029/2005g1023901, 2005.

Klink, J. M. and Smith, D. A.: Effect of wind changes during the last glacial maximum on the circulation in the Southern Ocean, Palaeooceanography, 8, 427-433, 1993.

LaBarbera, C. H. and MacAyeal, D. R.: Traveling supraglacial lakes on George VI Ice Shelf, Antarctica, Geophys. Res. Lett., 38, L24501, doi:10.1029/2011g1049970, 2011.

Lennon, P. W., Loynes, J., Paren, J. G., and Potter, J. R.: Oceanographic observations from George VI Ice Shelf, Antarctic Peninsula, Ann Glaciol, 3, 178-183, 1982.

Liu, H. W. and Miller, K. J.: Fracture toughness of freshwater ice., J. Glaciol., 22, 135-143, 1979.

Lucchitta, B. K. and Rosanova, C. E.: Retreat of northern margins of George VI and Wilkins Ice Shelves, Antarctic Peninsula, Ann. Glaciol., 27, 41-46, 1998.

Luckman, A., Jansen, D., Kulessa, B., King, E. C., Sammonds, P., and Benn, D. I.: Basal crevasses in Larsen C Ice Shelf and implications for their global abundance, The Cryosphere, 6, 113-123, doi:10.5194/tc-6-113-2012, 2012.

MacAyeal, D. R., Scambos, T. A., Hulbe, C. L., and Fahnestock, M. A.: Catastrophic ice-shelf break-up by an ice-shelf-fragmentcapsize mechanism, J. Glaciol., 49, 22-36, 2003.

Martinson, D. G., Stammerjohn, S. E., Iannuzzi, R. A., Smith, R. C., and Vernet, W.: Western Antarctic Peninsula physical oceanography and spatio-temporal variability, Deep-Sea Res Pt. II, 55, 1964-1987, 2008.

McGrath, D., Steffen, K., Rajaram, H., Scambos, T., Abdalati, W., and Rignot, E.: Basal crevasses on the Larsen C Ice Shelf, Antarctica: Implications for meltwater ponding and hydrofracture, Geophys. Res. Lett., 39, L16504, doi:10.1029/2012g1052413, 2012.

Mercer, J. H.: West Antarctic Ice Sheet and $\mathrm{CO}_{2}$ greenhouse effect: A threat of disaster, Nature, 271, 321-325, 1978.

Mohr, J. J., Reeh, N., and Madsen, S. N.: Accuracy of threedimensional glacier surface velocities derived from radar interferometry and ice-sounding radar measurements., J. Glaciol., 49,
210-222, doi:10.3189/172756503781830791, 2003.

Morris, E. M. and Vaughan, D. G.: Spatial and temporal variation of surface temperature on the Antarctic Peninsula and the limit of viability of ice shelves., in: Antarctic Peninsula climate variability: Historical and Palaeoenvironmental Perspectives, Antarctic research series, edited by: Domack, E., AGU, Washington, 6168, 2003.

Padman, L., Fricker, H. A., Coleman, R., Howard, S., and Erofeeva, L.: A new tide model for Antarctic Ice Shelves and seas, Ann. Glaciol., 34, 247-254, 2002.

Padman, L., Costa, D. P., Dinniman, M. S., Fricker, H. A., Goebel, M. E., Huckstadt, L. A., Humbert, A., Joughin, I., Lenaerts, J. T. M., Ligtenberg, S. R. M., Scambos, T., and van den Broeke, M. R.: Oceanic controls on the mass balance of Wilkins Ice Shelf, Antarctica, J. Geophys. Res., 117, C01010, doi:10.1029/2011jc007301, 2012.

Parkinson, C. L. and Cavalieri, D. J.: Antarctic sea ice variability and trends, 1979-2010, The Cryosphere, 6, 871-880, doi:10.5194/tc-6-871-2012, 2012.

Paterson, W. S. B.: The Physics of Glaciers, 3 Edn., Permagon, 1994.

Payne, A. J., Vieli, A., Shepherd, A. P., Wingham, D. J., and Rignot, E.: Recent dramatic thinning of largest west Antarctic ice stream triggered by oceans, Geophys. Res. Lett., 31, L23401, doi:10.1029/2004g1021284, 2004.

Pearson, M. R. and Rose, I. H.: The dynamics of George VI Ice Shelf, Brit. Antarct. Surv. B, 52, 205-220, 1983.

Potter, J. R., Paren, J. G., and Loynes, J.: Glaciological and oceanography calculations of the mass balance and oxygen isotopes ratio of a melting ice shelf, J. Glaciol., 30, 161-170, 1984.

Potter, J. R., and Paren, J. G.: Interaction between ice shelf and ocean in George VI Sound, Antarctica, Antarct Res Ser, 43, 35$58,1985$.

Pritchard, H. D., Ligtenberg, S. R. M., Fricker, H. A., Vaughan, D. G., van den Broeke, M. R., and Padman, L.: Antarctic ice-sheet loss driven by basal melting of ice shelves, Nature, 484, 502-505, 10.1038/nature10968, 2012.

Rack, W., Doake, C. S. M., Rott, H., Siegel, A., and Skvarca, P.: Interferometric analysis of the deformation pattern of the northern Larsen Ice Shelf, Antarctic Peninsula, compared to field measurements and numerical modeling, Ann. Glaciol., 31, 205-210, 2000.

Rack, W. and Rott, H.: Pattern of retreat and disintegration of the Larsen B Ice Shelf, Antarctic Peninsula, Ann. Glaciol., 39, 505510, 2004.

Reynolds, J. M.: Lakes on George VI Ice Shelf, Antarctica, Polar. Rec., 20, 425-432, 1981.

Reynolds, J. M.: The structure of Wordie Ice Shelf, Antarctic Peninsula, Brit. Antarct. Surv. B, 80, 57-64, 1988.

Reynolds, J. M. and Hambrey, M. J.: The structural glaciology of George VI Ice Shelf, antartic Peninsula, Brit. Antarct. Surv. B, 79, 79-95, 1988.

Ridley, J. K.: Surface melting on Antarctic Peninsula ice shelves detected by passive microwave sensors, Geophys. Res. Lett., 20 , 2639-2642, doi:10.1029/93GL02611, 1993.

Rignot, E., Casassa, G., Gogineni, P., Krabill, W., Rivera, A., and Thomas, R.: Accelerated ice discharge from the Antarctic Peninsula following the collapse of Larsen B Ice Shelf, Geophys. Res. Lett., 31, L18401, doi:10.1029/2004GL020697, 2004. 
Rignot, E., Velicogna, I., van den Broeke, M. R., Monaghan, A., and Lenaerts, J.: Acceleration of the contribution of the Greenland and Antarctic Ice Sheets to sea level rise, Geophys. Res. Lett., 38, L05503, doi:10.1029/2011g1046583, 2011.

Roberts, S. J., Hodgson, D. A., Bentley, M. J., Smith, J. A., Millar, I. L., Olive, V., and Sugden, D. E.: The Holocene history of George VI Ice Shelf, Antarctic Peninsula from clast-provenance analysis of epishelf lake sediments, AAPG. Stud. Geol., 259, 258-283, 2008

Rott, H., Skvarca, P., and Nagler, T.: Rapid collapse of northern Larsen Ice Shelf, Antarctica Science, 271, 788-792, doi:10.1126/science.271.5250.788, 1996.

Rott, H., Rack, W., Nagler, T., and Skvarca, P.: Climatically induced retreat and collapse of northern Larsen Ice Shelf, Antarctic Peninsula, Ann. Glaciol., 27, 86-92, 1998.

Rott, H., Rack, W., Skvarca, P., and de Angelis, H.: Northern Larsen Ice Shelf - further retreat after the collapse., Ann. Glaciol., 34, 277-282, 2002

Rott, H., Rack, W., and Nagler, T.: Increased export of grounded ice after the collapse of northern Larsen Ice Shelf, Antarctic Peninsula, observed by ENVISAT ASAR, Geoscience and Remote Sensing Symposium, IGARSS 2007, IEEE International, 2007, 1174-1176, 2007.

Scambos, T. A., Hulbe, C., Fahnestock, M., and Bohlander, J.: The link between climate warming and break-up of ice shelves in the Antarctic Peninsula, J. Glaciol., 46, 516-530, 2000.

Scambos, T. A., Hulbe, C. L., and Fahnestock, M. A.: Climateinduced ice shelf disintegration in Antarctica, in: Antarctic Peninsula climate variability: Historical and Palaeoenvironmental Perspectives, Antarctic Research Series, edited by: Domack, E., AGU, Washington, 2003.

Scambos, T. A., Bohlander, J. A., Shuman, C. A., and Skvarca, P.: Glacier acceleration and thinning after ice shelf collapse in the Larsen B embayment, Antarctica, Geophys. Res. Lett., 31, L18402, doi:10.1029/2004g1020670, 2004.

Scambos, T. A., Fricker, H. A., Liu, C. C., Bohlander, J., Fastook, J., Sargent, A., Massom, R., and Wu, A. M.: Ice shelf disintegration by plate bending and hydro-fracture: Satellite observations and model results of the 2008 Wilkins Ice Shelf break-ups., Earth Planet Sci. Lett., 280, 51-60, doi:10.1016j.eps1.2008.12.027, 2009.

Shepherd, A., Wingham, D., Payne, T., and Skvarca, P.: Larsen Ice Shelf has progressively thinned, Science, 302, 856-859, doi:10.1126/science.1089768, 2003.

Shepherd, A., Wingham, D., and Rignot, E.: Warm ocean is eroding west Antarctic ice sheet, Geophys. Res. Lett., 31, L23402, doi:10.1029/2004g1021106, 2004.

Shuman, C. A., Zwally, H. J., Schutz, B. E., Brenner, A. C., DiMarzio, J. P., Suchdeo, V. P., and Fricker, H. A.: Icesat Antarctic elevation data: Preliminary precision and accuracy assessment, Geophys. Res. Lett., 33, L07501, doi:10.1029/2005g1025227, 2006.
Siegfried, M. R., Hawley, R. L., and Burkhart, J. F.: High-resolution ground-based GPS measurements show intercampaign bias in ICESat elevation data near summit, Greenland, IEEE T. Geosci. Remote, 49, 3393-3400, doi:10.1109/tgrs.2011.2127483, 2011.

Simmons, D. A. and Rouse, J. R.: Geomagnetic measurements made on the moving ice shelf at Halley, Antarctica, Surv. Geophys., 6, 407-417, 1984

Simmons, D. A.: Flow of the Brunt Ice Shelf, Antarctica, derived from Landsat images, 1974-1985, J. Glaciol., 32, 252-254, 1986.

Skvarca, P.: Fast recession of the northern Larsen Ice Shelf monitored by space images., Ann. Glaciol., 17, 317-321, 1993.

Smith, J. A., Bentley, M. J., Hodgson, D. A., and Cook, A. J.: George VI Ice Shelf: Past history, present behaviour and potential mechanisms for future collapse, Antarct. Sci., 19, 131-142, doi:10.1017/S0954102007000193, 2007.

Stephenson, A. and Fleming, W. L. S.: King George the Sixth Sound, Geogr. J., 96, 153-164, 1940.

Swithinbank, C., Brunk, K., and Sievers, J.: A glaciological map of Filchner-Ronne Ice Shelf, Antarctica, Ann. Glaciol., 11, 150 155,1988

Talbot, M. H.: Oceanic environment of George VI Ice Shelf, Antarctic Peninsula, Ann. Glaciol., 11, 161-164, 1988.

Torinesi, O., Fily, M., and Genthon, C.: Variability and trends of the summer melt period of Antarctic ice margins since 1980 from microwave sensors, J Climate, 16, 1047-1060, doi:10.1175/1520-0442(2003)016<1047:vatots > 2.0.co;2, 2003.

Vaughan, D. G.: Implications of the break-up of Wordie Ice Shelf, Antarctica for sea level, Antarct. Sci., 5, 403-408, 1993.

Vaughan, D. G.: Tidal flexure at ice shelf margins., J. Geophys. Res., 100, 6213-6224, 1995.

Vaughan, D. G., Marshall, G. J., Connolley, W. M., Parkinson, C., Mulvaney, R., Hodgson, D. A., King, J. C., Pudsey, C. J., and Turner, J.: Recent rapid regional climate warming on the Antarctic Peninsula, Climat. Change, 60, 243-274, doi:10.1023/a:1026021217991, 2003.

Vieli, A., Payne, A. J., Shepherd, A., and Du, Z.: Causes of precollapse changes of the Larsen B Ice Shelf: Numerical modelling and assimilation of satellite observations, Earth Planet Sci. Lett., 259, 297-306, 2007.

Wager, A. C.: Flooding of the ice shelf in George VI Sound, Brit Antarct Surv. B., 28, 71-74, 1972.

Ward, C. G.: The mapping of ice front changes on Muller Ice Shelf, Antarctic Peninsula, Antarct. Sci., 7, 197-198, 1995.

Watson, D. F.: Contouring: A guide to the analysis and display of spatial data, Oxford, Pergamon, 1992.

Yuan, X. and Martinson, D. G.: Antarctic sea ice extent variability and its global connectivity, J. Climate, 13, 1697-1717, 2000. 